\title{
Information Services Directory
}

January 1991

U.S. Department of Energy

Office of Civilian Radioactive Waste Management

Washington, DC 20585

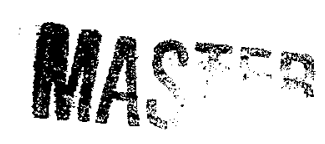




\section{DISCLAIMER}

This report was prepared as an account of work sponsored by an agency of the United States Government. Neither the United States Government nor any agency thereof, nor any of their employees, make any warranty, express or implied, or assumes any legal liability or responsibility for the accuracy, completeness, or usefulness of any information, apparatus, product, or process disclosed, or represents that its use would not infringe privately owned rights. Reference herein to any specific commercial product, process, or service by trade name, trademark, manufacturer, or otherwise does not necessarily constitute or imply its endorsement, recommendation, or favoring by the United States Government or any agency thereof. The views and opinions of authors expressed herein do not necessarily state or reflect those of the United States Government or any agency thereof. 


\section{DISCLAIMER}

Portions of this document may be illegible in electronic image products. Images are produced from the best available original document. 


\section{Table of Contents}

Introduction

OCRWM Headquarters Organization Chart

Yucca Mountain Site Characterization Project Office Organization Chart ..................4

I. Current Information Services ..........................................................................................5

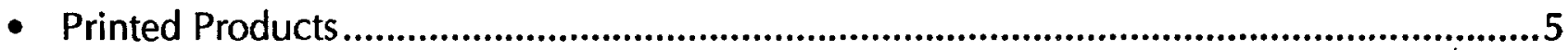

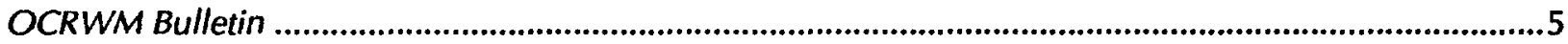

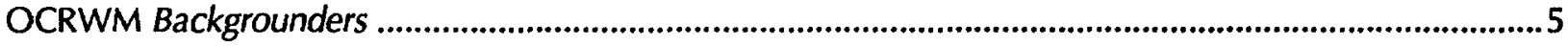

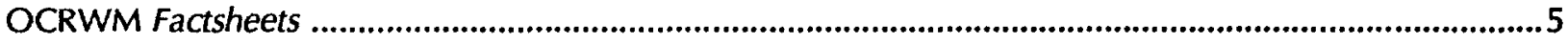

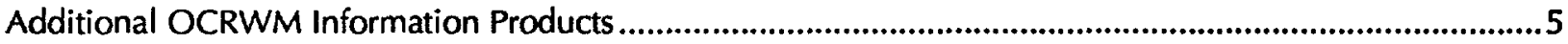

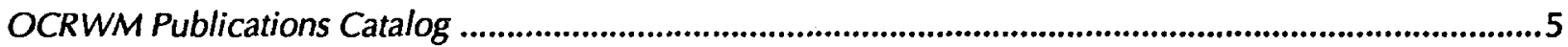

Radioactive Waste Management, A Current Awareness Publication ........................................................5

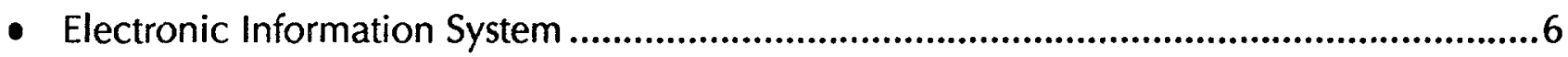

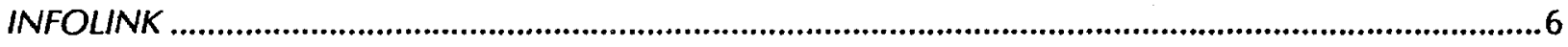

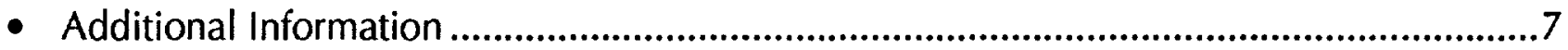

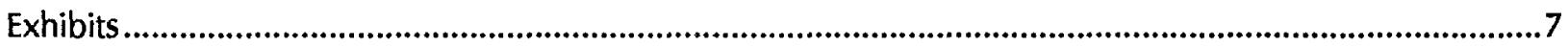

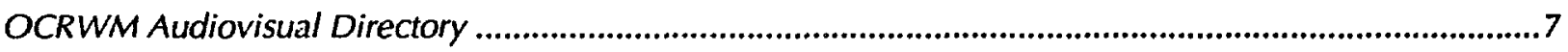

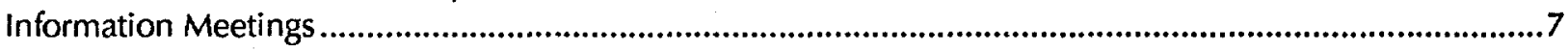

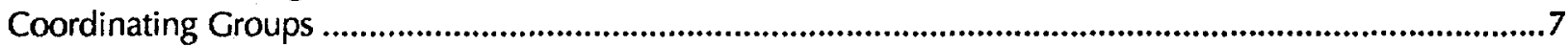

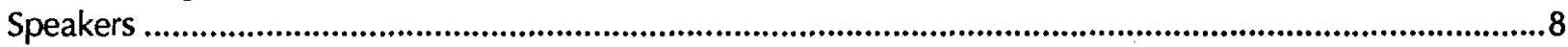

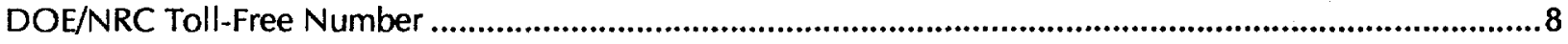

II. DOE, State and Federal Agency Contacts ........................................................9

- Project Offices and Additional DOE Offices .......................................................................

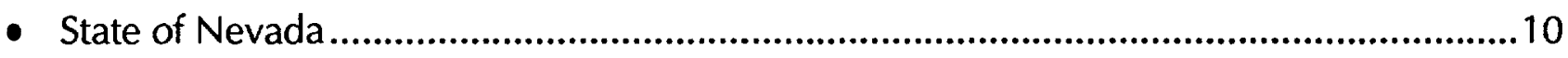

- Nevada Units of Government .......................................................................................

- Other Federal Agencies ..........................................................................................................11

- Independent Review Boards and Offices .........................................................................12

III. Technical Information ...............................................................................13

- DOE Technical Data Bases ..........................................................................................13

Licensing Support Systems (LSS) ..........................................................................................................13

Radioactive Materials Packaging Data Base (RAMPAC) .......................................................................13

Computerized Transportation Programs ...............................................................................................13

Highway ..........................................................................................................................14

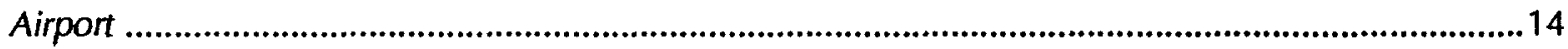

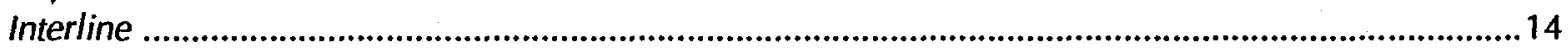

Transportation Legislative Data Base (TLDB) ................................................................................15 
- Additional DOE Technical Resources .........................................................................16

Technical Publications and Data Bases: Office of Scientific and Technical Information (OSTI) ................. 16

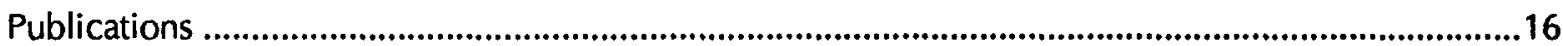

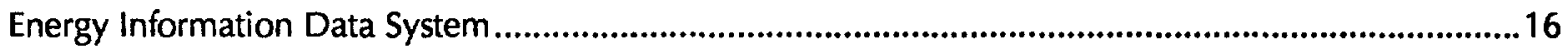

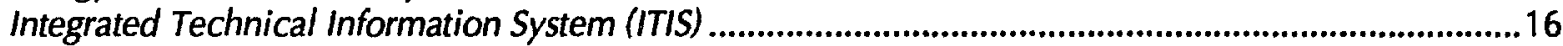

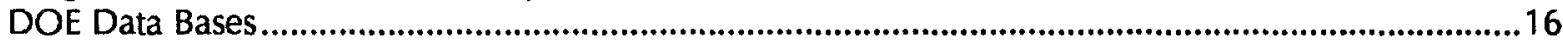

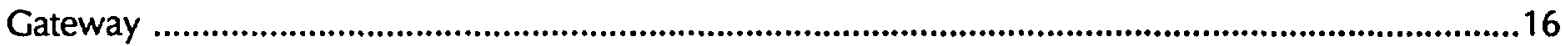

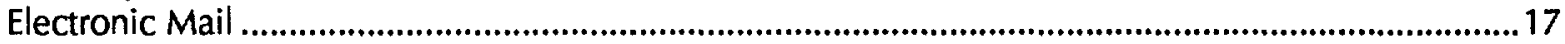

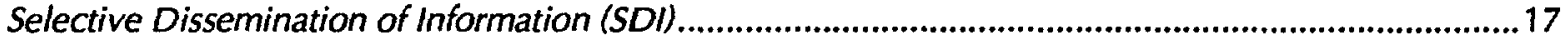

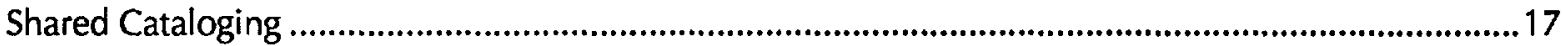

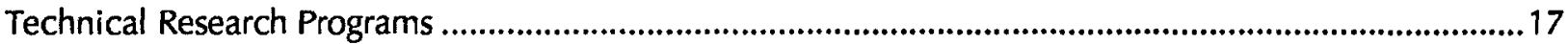

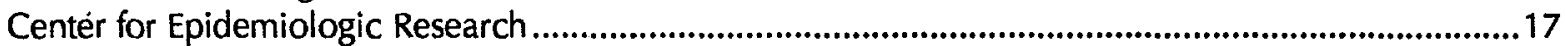

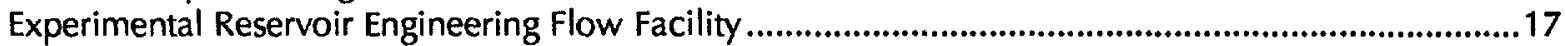

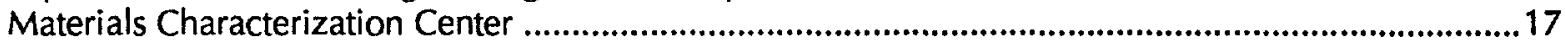

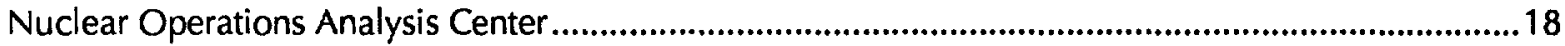

Radiation Emergency Assistance Center/Training Site (REAC/TS) .................................................18

Technical Software Programs: National Energy Software Center ..............................................................18

IV. Congressional Committees and Subcommittees ........................................31

- United States Senate ................................................................................................................

- United States House of Representatives ..................................................................................31

- Congressional Support Agencies ........................................................................................32

V. National and Regional Associations and Interest Groups................................33

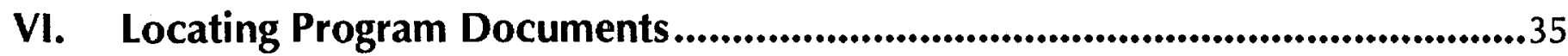

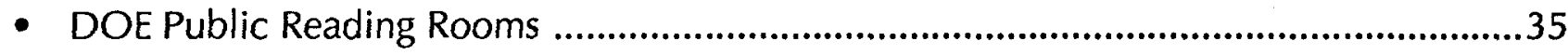

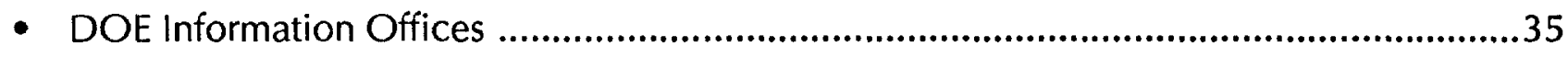

- NRC Local Public Document Rooms .................................................................................35

- Nevada Public Libraries ........................................................................................................36

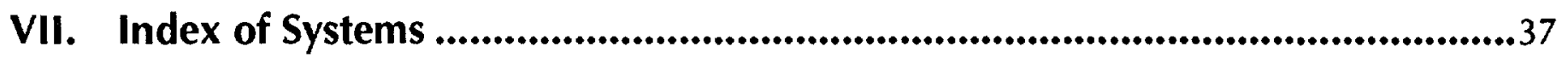

VIII. List of Selected Publications ....................................................................39 


\section{Introduction}

Congress passed the Nuclear Waste Policy Act of 1982 (NWPA) and its amendments establishing the National policy for safely storing, transporting and disposing of spent nuclear fuel and high-level radioactive waste in a geologic repository. This legislation created the Office of Civilian Radioactive Waste Management (OCRWM) within the U.S. Department of Energy (DOE) to develop an integrated system for the safe and efficient disposal of high-level radioactive waste. (An organization chart for OCRWM is provided on page 3.) OCRWM is funded by the owners and generators of spent fuel and high-level waste. The NWPA and its amendments also provide for participation in the Civilian Radioactive Waste Management Program by States, Indian Tribes and the public.

The NWPA, as amended, directs DOE to study in detail the Yucca Mountain site in Nevada as the only candidate site for the Nation's geologic repository. In Nevada, the DOE/OCRWM Yucca Mountain Site Characterization Project Office (YMPO) manages scientific investigations to determine the suitability of Yucca Mountain for effectively isolating radioactive waste from the public and the environment. (An organization chart for YMPO is provided on page 4.)

DOE is committed to ensuring a full and timely flow of information about the program to all affected and interested parties and to providing frequent opportunities, both formal and informal, for the fullest possible participation in the program. Achieving these goals depends on developing, maintaining and disseminating information that meets the needs and addresses the concerns of affected States and Indians Tribes, local governments, affected citizens, other interested parties and the general public.
This Information Services Directory is intended to facilitate dissemination of information. The Directory is produced by the Education and Information Division of OCRWM's Office of External Relations and will be updated periodically. This is the third such update since its issuance in August 1986. It is a reference document that lists the sources of program information available to States, Indian Tribes and the public.

Chapter I of this Directory describes current program information sources, including the OCRWM Bulletin, the Electronic Bulletin Board (INFOLINK) and other periodic publications produced by OCRWM and DOE's Office of Scientific and Technical Information (OSTI). Chapter II is an index of DOE, State and Federal Agency contacts. Chapter III provides a directory of DOE technical information and includes descriptions of computerized data bases and other resources. Chapter IV enumerates Congressional Committees and Subcommittees that have jurisdiction over various components of the Civilian Radioactive Waste Management Program, and Chapter $V$ lists national and regional associations and interest groups that have participated in waste management forums. Chapter VI lists DOE Public Reading Rooms and Information Offices, NRC Local Public Document Rooms, and public libraries in the State of Nevada that are on one or more of OCRWM's mailing lists. Chapter VII is an index of systems and Chapter VIII offers a listing of selected publications.

Suggestions and comments concerning this Directory will be appreciated. Comments should be directed to:

\author{
U.S. Department of Energy \\ Office of Civilian Radioactive Waste Management \\ Education and Information Division \\ 1000 Independence Avenue, SW \\ Washington, DC 20585 \\ (202) 586-5722
}





\section{Office of Civilian Radioactive Waste Management}

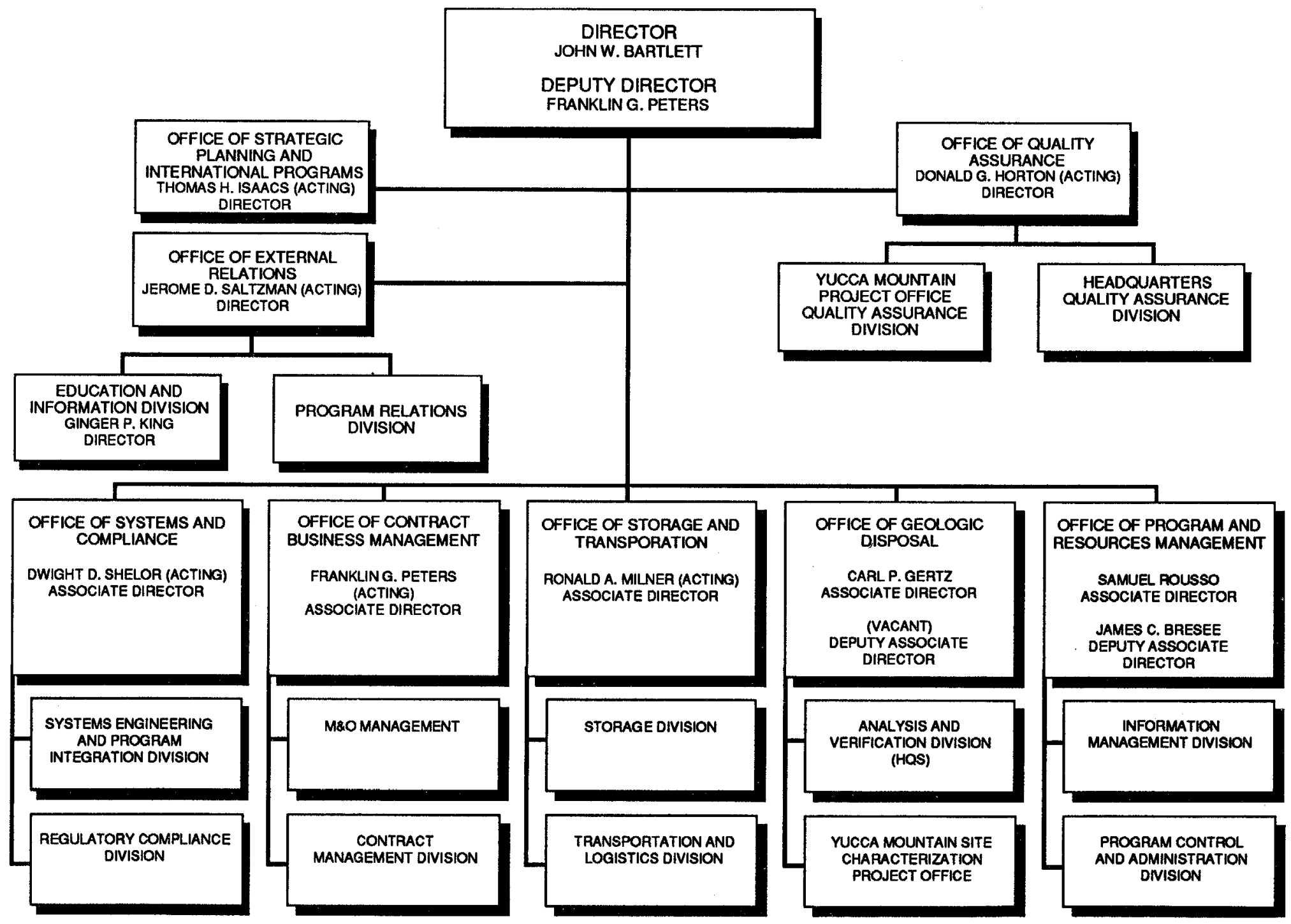




\section{Office of Geologic Disposal and Yucca Mountain Site Characterization Project Office Organization}

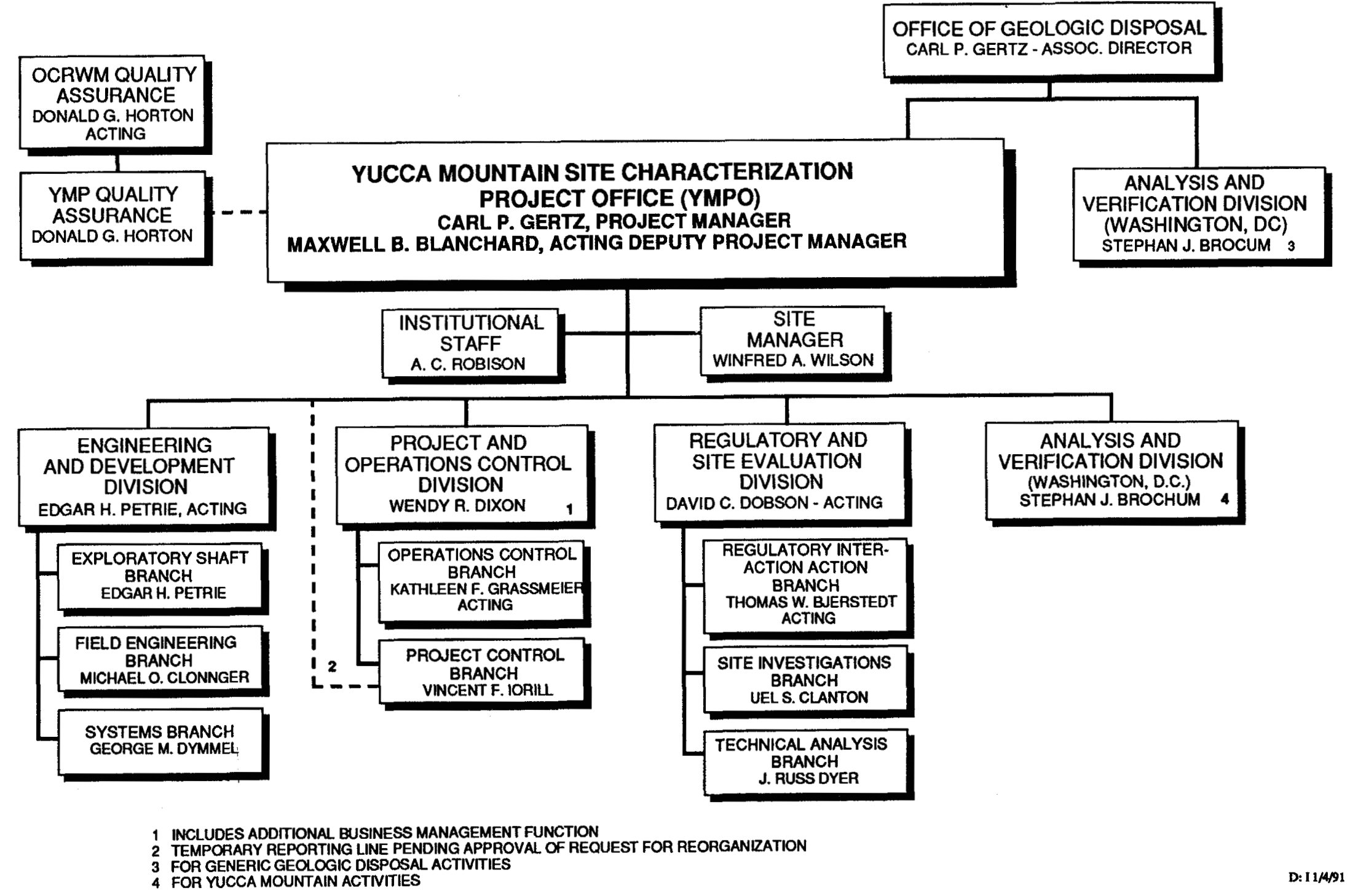




\title{
I. Current Information Services
}

To obtain information or to be added to the mailing list for any of the materials or services noted, contact:

\author{
U.S. Department of Energy \\ Office of Civilian Radioactive Waste Management \\ Education and Information Division \\ 1000 Independence Avenue, SW \\ Washington, DC 20585 \\ (202) $586-5722$
}

\section{Printed Products}

\section{OCRWM \\ Bulletin}

The OCRWM Bulletin, a monthly publication, provides information about OCRWM program activities, milestones, events, publications and documents to assist interested individuals in keeping abreast of the OCRWM program. The OCRWM Bulletin is distributed to Federal, State, Tribal and local officials; the media; other organizations and private citizens interested in current information regarding OCRWM activities. In addition, the text of the Bulletin is available on INFOLINK (see page 6).

\section{OCRWM}

Backgrounders
The OCRWM Backgrounders provide current background information on program facts, issues and initiatives. Backgrounders are published periodically by the Education and Information Division and are distributed to individuals and organizations on the OCRWM Bulletin mailing list and by individual requests.

\section{OCRWM}

Factsheets
OCRWM has published factsheets that are available for distribution to the public. The factsheets currently available describe the overall OCRWM program, the repository program, the monitored retrievable storage (MRS) system and the transportation program.

\section{Additional OCRWM Information Products}

OCRWM provides a number of printed products which are available to the public upon request. These products cover a variety of areas related to the management of spent fuel and high-level radioactive waste and include international brochures describing the United States' and other countries' programs. In addition, Managing the Nation's Nuclear Waste provides an overview of the integrated U.S. Waste Management System. A list of general publications can be found on page 39 of this Directory.

OCRWM

Publications

Catalog
OCRWM has published a catalog that contains abstracts of printed documents on the topic of high-level radioactive waste management that are of interest to Federal, State and local government officials and staff; affected Indian Tribes; advisory groups; special interest groups; the media; information science professionals; students and the general public. The catalog features citation listings alphabetically by titles, an index by keywords and an index by corporate authors. In addition to a printed catalog, the information is available online through the OCRWM Product Record System (see page 6). The catalog is updated monthly online.

\section{Radioactive Waste Management, A Current Awareness Publication}

Radioactive Waste Management is a monthly publication that provides digests of current information available on the topics of spent fuel transport and storage, radioactive effluents from nuclear facilities, techniques of processing radioactive waste, remedial actions and environmental aspects of radioactive waste management. This bulletin is published by DOE's Office of Scientific and Technical Information (OSTI) in Oak Ridge, Tennessee. OCRWM is providing subscriptions to affected States and local governments. Other parties wishing to receive this publication should telephone (703) $487-4630$ and request document number PB90-902900. 


\section{Electronic Information System}

INFOLINK
INFOLINK is a computerized data base and communications network created to assist users in accessing OCRWM program information as well as in identifying and ordering OCRWM information products. Through INFOLINK you can:

- $\quad$ Access Current Information

INFOLINK maintains a Bulletin Board that provides the most current OCRWM program information. An Alert/Newsflash feature provides current information and DOE positions on waste management developments. Full text of OCRWM press releases, selected speeches, technical papers, Congressional testimony, and the current OCRWM Bulletin are available on-line to inform users about program developments.

In addition, the INFOLINK Bulletin Board maintains the complete text of all recent OCRWM Backgrounder documents, providing subject-specific information on selected topics.

Complete text for all information can be read directly from the PC screen or printed directly on the user's printer.

- $\quad$ Place Orders

Orders can be placed electronically for any available OCRWM product with INFOLINK. Requests are received directly at the distribution office and filled promptly.

- Review Information Products

INFOLINK permits a review of a directory of OCRWM selected printed products, exhibits, and audiovisual materials. Any of 300 titles available for distribution by OCRWM can be previewed. These products can be accessed by DOE/RW number, subject area, publication date, or type of product. Descriptions and abstracts for all the products are provided.

INFOLINK also provides access to the OCRWM Publications Catalog citing selected technical and public information documents from OCRWM and other sources on high-level radioactive waste.

A compilation and index for the previous OCRWM Bulletins is available for easy reference searches. Complete text of all OCRWM Bulletins from January 1988 is available.

Product information for all OCRWM products can be read on the screen or printed on a PC printer. Information can also be saved by user accounts and the printout mailed to the user.

- Communicate

INFOLINK allows any user on the system to send or receive text files. Networks can be arranged to provide an exchange of information with preselected users. For example, agendas, meeting notices, messages, or files can be sent to or received by identified users to assist in coordinating activities at a variety of locations.

For more information about INFOLINK, contact:

U.S. Department of Energy

Office of Civilian Radioactive Waste Management

Education and Information Division (INFOLINK)

1000 Independence Avenue, SW

Washington, DC 20585

(202) 586-5722 


\section{Additional Information}

\section{Exhibits}

OCRWM has two large exhibits (one is $10^{\prime} \times 20^{\prime}$ and the other is $20^{\prime} \times 20^{\prime}$ ), and several tabletop $\left(3^{\prime} \times 8^{\prime}\right)$ exhibits entitled Managing the Nation's Nuclear Waste which describe the radioactive waste management program. These exhibits are used at public meetings and events around the country. The full-size exhibits consist of a series of panels and videotapes. Each tabletop exhibit consists of five 3-foot panels displayed on an 8-foot long conference table. Each exhibit describes the basics of nuclear waste, the Nuclear Waste Policy Act and the Amendments Act and the proposed integrated waste management system. For further information on the OCRWM exhibits, write to:

\section{U.S. Department of Energy}

Office of Civilian Radioactive Waste Management

Education and Information Division

(Exhibits)

Washington, DC 20585

\section{OCRWM Audiovisual Directory}

The OCRWM Audiovisual Directory lists abstracts of videotapes, audiocassettes, slides and films on the subject of waste management. These products are available for loan to Federal, State and local governments; Indian Tribes; the media; professionals and the general public. The directory contains both current and historical footage and features citation listings numerically and alphabetically by titles. The directory also indexes products by subject keywords. In addition to a printed directory, the information is available online through INFOLINK.

\section{Information Meetings}

OCRWM holds periodic information meetings for interested and affected parties. These meetings are open to anyone with an interest in the program, including representatives from States, Indian Tribes, local governments, utilities, special interest groups and members of the general public.

The information meetings provide an opportunity for affected and interested parties to interact informally with each other as well as with OCRWM officials. Meetings may include presentations, workshops, discussion sessions and question and answer sessions. These meetings are announced in the OCRWM Bulletin and on INFOLINK.

\section{Coordinating Groups}

Coordinating groups have been organized in the past to provide DOE and affected States and Indian Tribes a forum for the discussion of common problems and their resolution. There is currently a Transportation Coordination Group, which meets approximately two times a year, and as a result of recommendations by the States and Indian Tribes. These meetings are open to the public and announced in the OCRWM Bulletin and on INFOLINK.

Additional coordinating groups may be established as requirements and priorities change. For information on the coordinating groups, contact:

U.S. Department of Energy

Office of Civilian Radioactive Waste Management

Education and Information Division

(Coordinating Groups)

Washington, DC 20585 
Members of the OCRWM program staff are available to speak to various groups interested in the radioactive waste management program. Qualified speakers can discuss the OCRWM program in general or address specific topics of special interest to a particular organization. To request a speaker, please write to:

\title{
U.S. Department of Energy
}

Office of Civilian Radioactive Waste Management

Education and Information Division

(Speaker)

Washington, DC 20585

\author{
or \\ YMPO Speakers' Bureau \\ Yucca Mountain Site Characterization Project Office \\ Mail Stop 523 \\ P.O. Box 98608 \\ Las Vegas, NV 89193-8608
}

\section{DOE/NRC \\ Toll Free Number}

An 800 telephone number has been established by DOE to announce upcoming technical meetings of DOE and the Nuclear Regulatory Commission (NRC). The public is invited to observe these meetings and may call the 800 telephone number to determine the date, time and location of the meetings. The telephone number is $(800) 368-2235$. In the Washington, DC, area call 479-0487.

A telephone recording service has been established for the announcement of upcoming meetings related to the waste management program of the NRC. The number is (800) 3685642, ext. 20436. Washington, DC, area residents should call 492-0436. 


\section{DOE, State and Federal Agency Contacts}

\section{U.S. Department of Energy}

Information on telecopy capabilities may be obtained by calling the individual offices listed below.

\section{Office of Civilian}

\section{Radioactive Waste Management}

Washington, DC

Office of Civilian Radioactive

Waste Management

U.S. Department of Energy

1000 Independence Avenue, SW

Washington, DC 20585

Director:

John W. Bartlett (202) 586-6842

Education and Information Division

Office of Civilian Radioactive

Waste Management

U.S. Department of Energy

1000 Independence Avenue, SW

Washington, DC 20585

\section{Director:}

Ginger P. King (202) 586-2835

Nevada

Yucca Mountain Site Characterization Project Office U.S. Department of Energy

Mail Stop 523

P.O. Box 98608

Las Vegas, NV 89193-8608

Project Manager:

Carl P. Gertz (702) 794-7900

Transportation Program

Chicago Operations Office

U.S. Department of Energy

9800 South Cass Avenue

Argonne, IL 60439

Director:

Dave Dashevsky (708) 972-2004

Senior Program Manager:

Jeffrey Roberts (708) 972-2228

Office of Communication:

Gary Pitchford (708) 972-2013

Institutional Programs:

Judith Holm (708) 972-2410
Nuclear Programs

Idaho Operations Office

U.S. Department of Energy

785 DOE Place

Idaho Falls, ID 83402

Civilian Rad-Waste Branch Chief: Margaret Fisher (208) 526-1466

\section{DOE/OCRWM} Information Offices

Yucca Mountain Information Office U.S. Department of Energy

P.O. Box 69

Beatty, NV 89003

Staff: Shirley Tarr

Phone: (702) 553-2130

Hours: 10 a.m.-3 p.m., Mon.-Fri.

12 p.m.-5p.m., Sat., Sun.

Yucca Mountain Information Office 4101B Meadows Lane

Las Vegas, NV 89107

Staff: Effie Harle

Phone: (702) 295-1312

Hours: 12 a.m.-6 p.m., Mon. 10 a.m.-6 p.m., Tues., Sat. 8 a.m.-6 p.m., Wed., Thurs., Fri. 11 a.m.-5 p.m., Sun.

\section{Nevada Operations Office}

Nevada Operations Office

U.S. Department of Energy

P.O. Box 98518

Las Vegas, NV 89193-8518

Manager:

Nick Aquilina (702) 295-3211

Nevada Operations Office

Office of External Affairs

U.S. Department of Energy

2753 South Highland Drive

Las Vegas, NV 89109

Director:

Chris West (702) 295-3521

\section{Chicago Operations Office}

Chicago Operations Office

U.S. Department of Energy

9800 South Cass Avenue

Argonne, IL 60439

Acting Manager:

Dr. David Goldman (708) 972-2110

Office of Communication:

Gary Pitchford (708) 972-2013

\section{Office of Environmental Restoration and Waste Management}

Office of Environmental Restoration and

Waste Management

U.S. Department of Energy

1000 Independence Avenue, SW

Washington, DC 20585

Director:

Leo Duffy (202) 586-7709

Office of Technology Development

Transportation Management

Division, EM-51

U.S. Department of Energy

Washington, DC 20545

Acting Director:

Susan Denny (301) 427-1604

Information and Communication: Joanne Passaglia (301) 427-1686 


\section{State of Nevada and Affected Units of Local Government}

On December 22, 1987, the President signed the Nuclear Waste Policy Amendments Act of 1987, which named Yucca Mountain, Nevada, as the only site to be studied to determine whether or not it is suitable for development of a repository.

\section{State of Nevada Repository Contact}

Nevada Nuclear Project Agency

Nuclear Waste Project Office

State of Nevada

Capitol Complex

Carson City, NV 89710

Executive Director:

Robert Loux, Ir. (702) 687-3744

\section{Contacts for Affected Units for Local Government}

Dennis Bechtel/Robert Palm

Clark County Department of Comprehensive Planning

225 Bridger Avenue, 7th Floor

Las Vegas, NV 89155

(702) 383-3530

Mike Baughman

Consultant for Lincoln County Intertech Consultants, Inc.

35 Clark Road

Fiskdale, MA 01518

Steve Bradhurst

Consultant for Nye County

Allen-Bradhurst Corporation

P.O. Box 1510

Reno, NV 89505

(702) 323-4141
Peter Cummings, Management Analyst Economic Development Department

City of Las Vegas

City Hall

400 East Stewart

Las Vegas, NV 89101

Jack Finney

Emergency Management Coordinator

City of Henderson

234 Water Street

Henderson, NV 89105

Jane Kinner

Planning Director

City of North Las Vegas

2200 Civic Center Drive

North Las Vegas, NV 89101 


\section{Other Federal Agencies}

\section{U.S. Department of Agriculture}

\author{
Assistant Secretary \\ Room 217E Administration Building \\ U.S. Department of Agriculture \\ Washington, DC 20250 \\ (202) 447-7173 \\ Environmental Coordinator \\ Office of the Secretary \\ Room 217E \\ Administration \\ U.S. Department of Agriculture \\ Washington, DC 20250 \\ (202) 447-7173
}

\section{U.S. Department of Commerce}

The Under Secretary

National Oceanic and

Atmospheric Administration

U.S. Department of Commerce

Washington, DC 20230

(202) $377-4080$

Acting General Counsel

for Ocean Services

U.S. Department of Commerce

Washington, DC 20230

(202) $377-4080$

\section{Council on \\ Environmental Quality}

Council on Environmental Quality

722 jackson Place, NW

Washington, DC 20503

(202) 697-2302

\section{U.S. Department of Defense}

Assistant Secretary of the Air Force for Manpower and Reserve Affairs The Pentagon

Washington, DC 20330

(202) 697-2302

Headquarters USAF/LEEV

Chief, Environmental Division

Directorate of Engineering and Services

Building 516, Bolling Air Force Base

Washington, DC 20332-55000

(202) $767-4178$
U.S. Army Corps of Engineers

Washington, DC 20314-1000

Chief of Engineers

(202) 272-0001

Directorate of Civil Works:

(202) 272-0099

\section{U.S. Environmental Protection Agency}

Director, Office of Federal Activities U.S. Environmental Protection Agency $401 \mathrm{M}$ Street, SW

A-104, Room 2119

Washington, DC 20460

(202) 382-5053

\section{Federal Emergency Management Agency}

Federal Emergency Management Agency

500 C Street, S.W.

Washington, DC 20472

(201) 646-4600

\section{U.S. Department of the Interior}

U.S. Department of the Interior 1849 C Street

Washington, DC 20240

(202) 208-3100

Assistant Secretary, Policy, Budget, and Administration: (202) 343-6182

Director, Environmental Project Review Office of the.Secretary: (202) 343-3891

Chief, Environmental Services Staff Bureau of Indian Affairs: (202) 343-4690

Environmental Quality Specialist Bureau of Indian Affairs: (202) 343-7684

Bureau of Land Management

Office of Public Affairs

Department of the Interior

Washington, DC 20240

(202) 343-7163

U.S. Geological Survey

12201 Sunrise Valley Drive

Reston, VA 22092

(703) 647-4000

\section{U.S. Department of Justice}

U.S. Department of Justice Land and Natural Resources Division Room 2143

601 Pennsylvania Avenue, NW

Washington, DC 20044

Assistant Attorney General: (202) 633-2701

Chief, Land Acquisition Section: (202) 272-6776

\section{U.S. Department of Labor}

Mine Safety and Health Administration U.S. Department of Labor

Boston Tower \#3

4015 Wilson Blvd.

Arlington, VA 22203

Assistant Secretary for Mine Safety and Health Administration: (703) 235-2600 Office of Health and Safety: (703) 235-8463, Room 508 Office of Technical Support: (703) 235-1582, Room 915

\section{Nuclear Regulatory Commission}

Nuclear Regulatory Commission Washington, DC 20555

Chairman: (202) 492-1759

Director: Office of Nuclear Material Safety and Safeguards: (202) 492-3352

Director: Office of Governmental and Public Affairs: (301) 492-0321

Division of Information Services: (202) 492-8585

General Counsel: Office of the General Counsel: (301) 492-1743

Meeting Information Number (recorded): (800)368-5642, ext. 20436

\section{U.S. Department of State}

Assistant Secretary for Oceans and International Environment and Scientific Affairs

U.S. Department of State Washington, DC 20520

(202) 647-1554 
Bureau of Oceans and International

Environmental and Scientific Affairs

U.S. Department of State

Washington, DC 20520

(202) 235-9376

\section{U.S. Department of Transportation}

Office of Hazardous Materials Transportation Research and Special Programs Administration U.S. Department of Transportation (DHM-51) 400 Seventh Street, SW

Washington, DC 20590

(202) 366-4488

\section{Independent Review Boards and Offices}

\section{Nuclear Waste Technical Review Board}

Nuclear Waste Technical Review Board 1100 Wilson Blvd.

Suite 910

Arlington, VA 22209

Executive Director: William B. Barnard

Phone: (703) 235-4473

Members:

For a term of four years expiring April 19, 1992: Don U. Deere Clarence R. Allen John E. Cantlon

Melvin W. Carter

Donald Langmuir

For a term of four years expiring April 19, 1994: Dennis L. Price Patrick A. Domenico

For a term of four years expiring March 1994: D. Warner North

Awaiting reappointment for four-year term: Ellis D. Verink

\section{Office of the \\ United States Negotiator}

Headquarters:

Boise, ID 83777

Negotiator: David H. Leroy

Phone: (208) 334-9876

Washington, DC, Liaison Office:

1823 Jefferson Place, NW

Washington, DC 20036

Negotiator: David H. Leroy

Phone: (202) 634-6244

According to the NWPA, as amended, the office will cease to exist on January 21, 1993. 


\section{Technical Information}

Technical information on the high-level radioactive waste management program and related research programs is available from numerous sources. OCRWM and its Project Offices have established computerized data bases to make technical program information available to States, Indian Tribes and local governments. Brief descriptions of data bases and information on accessing them is given below. In addition, technical information related to radioactive waste is available through other DOE facilities as indicated below. (An index of these systems is on page 37.)

\section{DOE Technical Data Bases}

\section{Licensing Support System (LSS)}

The Department of Energy is in the process of developing the Licensing Support System (LSS) data base. This system will be capable of storing, searching and retrieving, in full text, the records and documents needed for the licensing of a geologic repository for the disposal of high-level radioactive waste.

\section{Radioactive Materials Packaging Data Base (RAMPAC)}

A data base that serves the overall operational transportation programs of DOE is available. RAMPAC was developed to organize information on packaging from three government agencies into a computerized data base. RAMPAC contains descriptive entries of packaging models certified by the Nuclear Regulatory Commission (NRC), DOE and those covered by a U.S. Department of Transportation (DOT)
Certificate of Competent Authority for international shipments. With the information available from this data base, users can determine which packaging can be used to transport specific materials, and/or obtain information on certificates such as expiration dates and other users of the packaging, as well as specific information on the packaging design and usage.

RAMPAC includes information on over 650 packagings, and the data for each entry may include the following information: certificate number; the type of packaging (Type A, B or S); the fissile class of the materials the package may carry; the kind of packaging (drum, cask, etc.); the authorized contents (e.g., irradiated fuel, plutonium special form); the gross weight; the payload; the mode of transportallowed (air, highway, rail, water); cavity dimensions; exterior dimensions; the model name of the packaging; the type of license issued; the issue and expiration dates of the certificate; package shielding; package contents; and potential contacts for the packaging.

For more information on RAMPAC, contact:

Analysas Corporation

101A East Tennessee Ave.

Oak Ridge, TN 37830

(615) $576-9119$

\section{Computerized Transportation Programs}

A major thrust of the transportation programs at the Oak Ridge National Laboratory (ORNL) has been the development of a number of computerized transportation programs and data bases. It is important to note that specific routes to be used for the disposal system being developed under the NWPA will not be determined until a site is selected and approved for a repository. 
For information about accessing three ORNL data bases Highway, Airport and Interline - contact:

\author{
Transportation Technology Group \\ Oak Ridge National Laboratory \\ Building 4500 North \\ Mail Stop 6273 \\ P.O. Box 2008 \\ Oak Ridge, TN 37831-6227 \\ (615) $576-2068$
}

\begin{abstract}
Highway
Highway provides a flexible tool for predicting highway routes for transporting radioactive materials in the United States. The Highway data base is essentially a computerized road atlas that currently describes over 245,000 miles of highways, identifying some 20,100 highway segments which connect approximately 13,200 intersections. The data base includes a description of the Interstate Highway System and essentially all U.S. highways. Most of the principal State highways and a number of local and county highways are also identified. Recent additions to the data base include the locations of nuclear facilities and major airports.
\end{abstract}

Highway can be used to generate routes that take a set of user-supplied constraints into consideration. Routes are calculated by minimizing a mathematical function between the origin of the shipment and its destination. In addition, several routing constraints can be imposed during the calculation. For example, routes that maximize the use of the Interstate Highway System can be generated. This constraint simulates the route that would be used to transport highway route-controlled quantities of radioactive materials between two points (HM-164 requirements). In addition, the model is capable of calculating routes that bypass a specific State, city, town or a specific highway segment. This constraint can be extrapolated to delete all highway segments located within urbanized areas containing over 100,000 people. Routes generated from this constraint will bypass these urbanized areas.

Highway's normal output includes a brief summary showing the origin, destination, departure and arrival times, estimated driving time and total distance for a given route. Mileage driven in each State is also listed along with the mileage traveled on the various highway types. Even more detailed information can be obtained when needed.

\section{Airport \\ Airport is an airport locator program developed to provide DOE quick access to emergency response information in responding to incidents that may involveradioactive materials.}

The program includes a data base listing approximately 800 commercial and military airports in the continental United States that could be used in transporting specialized equipment and/or personnel to a particular site. The data base includes a description of the major runways at each airport, including information on geographic coordinates, instrument approach capabilities and length, width, surface and weight-bearing capacity of runways.

Airport is designed to find all the airports in the vicinity of a predetermined location. The central position used for the search is a highway intersection derived from the Highway model. Airport establishes a search window centered at this location with approximate dimensions of $300 \times 300$ square miles; all airports within the window that meet specified criteria are extracted from the data base. The line-of-flight distance between the airports and the central point is calculated, and the airports are listed in order of their distance from the center. The user can request that the driving time be calculated for each airport appearing in the list. To perform this function, the Airport and Highway programs have been integrated. When driving times are requested, the list of airports will be rearranged in order of the driving time to the point of interest.

If desired, several constraints specifying airport capabilities can be included, and only the airports which satisfy these constraints will be reported. The user-specified constraints may include minimum runway length, instrument approach capability and aircraft landing weight.

\section{Interline}

Interline is an interactive program designed to simulate routing practices on the U.S. rail system. Because the rail industry is divided into a large number of independent competing companies, Interlinedivides the U.S. rail network into 95 separate subnetworks to better simulate the routing practices of an individual company.

The data base used by Interline was originally obtained from the Federal Railroad Administration and reflected 1974 data. It has been modified as of 1987 to reflect corporate mergers and line abandonments, new construction and line density classification changes as railroads have modified their routing practices.

An important element of the data base is a file indicating where traffic may move from one rail line to another. This information is important because transfers between railroads involve additional cost and delay. The data base assigns penalties to these transfer points to replicate the tendency to keep traffic on a single railroad's lines when possible. 
By varying a number of parameters, the user can find alternative routes and examine the effect of restricting movement through specified areas. These alternative, nondirect routes must always be evaluated for feasibility because the program may predict a route over poor quality track and because nonstandard routes often require the development of special arrangements with the railroads.

Recently, the Interlinemodel was expanded to include the capability of predicting barge routes. The barge network includes inland waterways, intercoastal waterways, Great Lakes shipping routes and deep-water routes in the Gulf of Mexico and the Atlantic and Pacific Oceans. Approximately 100 ports are included in the model. Each port is described by its capacity to load freight, crane capacity and railroads providing access to the port. Nuclear reactor sites along navigable waterways are also identified in the network.

\section{Transportation Legislative Data Base (TLDB)}

The Transportation Legislative Data Base (TLDB) is a comprehensive source of accurate, concise information on Federal and State regulation of radioactive materials transportation that is dedicated to serving the information needs of DOE, other Federal agencies, State, Tribal and local governments, the hazardous materials transportation industry and interested members of the general public. The TLDB provides:

- Complete information - Indexed summaries of all known and available federal and State statutes, regulations and pending legislation concerning the transportation of radioactive waste.

- Accurate Information - Compiled and systematically verified by experienced transportation counsel through direct contact with the Federal Government and the various State legislatures and administrative agencies. Correct and current citations are given for each entry in the database.

- Concise Information-Concise summaries of all statutory, regulatory and pending legislative actions, clearly explaining their essential provisions and requirements. All entries are indexed according to the principal transportation topics of interest.
The following information products and services are produced utilizing information from the TLDB and are offered at no charge to interested organizations and individuals:

- Legal Developments Reports - Quarterly and annual reports providing concise, relevant explanation of important legal documents concerning radioactive materials transportation at the Federal, State, and if available, Tribal and local levels of government.

- Issue-Oriented Reports - Specific analytical reports on key issues of interest in the area of Federal and State regulation of radioactive materials transportation (e.g., State permitting and licensing requirements, routing requirements, etc.).

- Individual Responsesto Specific Information Requests $T L D B$ staff perform customized searches of the $T L D B$ in response to specific inquiries and forward printouts to requestors by facsimile or mail.

- On-Line Access - Direct access to the TLDB will be provided to interested organizations and individuals with appropriate equipment (i.e., a personal computer with a communications modem and terminal emulation software).

In addition to the products and services noted above, other reports or bulletins may be produced on occasion in response to significant legal developments, requests from users of the system or other topics of interest to a broad audience. TLDB subscribers will receive more detailed information on such products as they become available.

To receive more information on the $T L D B$, contact:

Judith Holm Chicago Operations Office U.S. Department of Energy 9800 South Cass Avenue Argonne, IL 60439

(708) 972-2410 


\section{Additional DOE Technical Resources}

Other resources available at DOE facilities include the following:

- technical publications and data bases available through the Office of Scientific and Technical Information (OSTI) in Oak Ridge, Tennessee;

- technical research programs operated by DOE and the Nuclear Regulatory Commission (NRC); and

- technical software programs available through the National Energy Software Center, operated for OSTI by Argonne National Laboratory in Argonne, Illinois.

\section{Technical Publications and Data Bases: Office of Scientific and Technical Information (OSTI)}

OSTI, located in Oak Ridge, Tennessee, has been the national center for scientific and technical information for DOE and its predecessor agencies since 1946. In developing and managing DOE'stechnical information program, OSTI places DOE-originated information as well as worldwide literature on scientific and technical advances in the energy field under bibliographic control and announces the source and availability of this information. Although the literature of science is emphasized, coverage is extended to DOE programmatic, socioeconomic, environmental, legislative/ regulatory, energy analysis and policy-related areas.

To obtain general information about OSTI's services in relation to publications and data bases on radioactive waste, contact:

\section{U.S. Department of Energy}

Office of Scientific and Technical Information

P.O. Box 62

Oak Ridge, TN 37831

(615) $576-0140$

\section{Publications}

The publications received and processed by OSTI include reports, books, conference summaries, monographs, dissertations, patents and journal articles. In many cases, individual papers, sections, chapters, etc., from books, conferences and reports are catalogued separately.

\section{Energy Information Data System}

To accomplish its mission, OSTI builds and maintains computerized energy information data bases and disseminates this information via computerized retrieval systems and announcement publications, such as bibliographies and current awareness periodicals (see Chapter 1 regarding State and Indian Tribe subscriptions to OSTI publications). Direct access to OSTI's most comprehensive data base, Energy Data Base (EDB), is available to the public through commercial online bibliographic retrieval systems. (On some of these systems, $E D B$ is known as $D O E$ Energy.) $E D B$ was initiated in 1974 and is presently the world's largest and most comprehensive data base on energy. It includes many publications related to radioactive waste management. $E D B$ and other energy-related data bases are available to DOE offices and contractors and to other government agencies via ITIS, the Department's online information retrieval system.

\section{Integrated Technical Information System (ITIS)}

Online capabilities developed by DOE's Office of Scientific and Technical Information (OSTI) provide efficient and timely services to users of the DOE information system. The Integrated Technical Information System (ITIS) provides access to the OSTI data bases and serves as a gateway to other government and commercial online systems, and provides information merging for customized information products. Electronic mail through ITIS serves as a communications link with OSTI, DOE and contractor offices. ITIS replaced DOE/ RECON, which was discontinued as of December 31, 1986.

Five components of ITIS follow in this section.

\section{DOE Data Bases}

A major component of ITIS is the collection of DOE data bases retrievable through the system. Library specialists, information managers and researchers can carry on dial ogues directly with the OSTI computer from remote terminals to search such data bases as Energy (current year) and Research in Progress. Users can review search results at their personal computer terminals, download the data or receive printed copy, which is processed overnight and mailed the following morning.

Various specialized DOE data bases can also be accessed through the system.

\section{Gateway}

A gateway to other online systems, ITIS provides access to Federal data bases and other online systems such as NASA RECON, DOD/DTIC, EDB (the entire data base) and NTIS on commercial systems. Data can be downloaded from these systems, merged into a common format and checked for duplicate references to produce custom bibliographies with author and subject indexes. 


\section{Electronic Mail}

The electronic mail capability of ITIS creates a communications link among users of DOE's scientific and technical information. It also provides direct access to OSTI staff for online ordering of documents and direct technical assistance.

\section{Selective Dissemination of Information (SDI)}

The ITIS system enables users to receive information on specifically selected topics through Selective Dissemination of information (SDI). Once the user has established a "profile" defining an individual area of interest, he or she will receive a printout of current references and abstracts on a regular basis.

\section{Shared Cataloging}

Currently, OSTI receives and catalogs approximately 25,000 reports each year. These same reports are cataloged by DOE contractors and other organizations. Sharing the initial cataloging of bibliographic data for technical reports will eliminate costly duplication, facilitate libraries' maintaining online catalogs of hard copy and microfiche and allow libraries to create announcement publications more efficiently.

For additional information and authorization to access ITIS, contact

U.S. Department of Energy

Office of Scientific and Technical Information

P.O. Box 62

Oak Ridge, TN 37831

(615) $576-1026$

\section{Technical Research Programs}

DOE and the NRC operate research programs that relate to radioactive waste and that may provide technical information to States and Tribes.

\section{Center for Epidemiologic Research}

Research programs are conducted to examine relationships between occupational exposure to ionizing radiation and subsequent health and mortality. The health effects of chemical toxicants, especially uranium and other metals, are also being investigated both as primary and confounding (with respect to radiation) occupational stresses. Biostatisticians and computer scientists are implementing improved methods for epidemiological analyses and data systems for merging large masses of data into analysis files. Editing and correction procedures have been developed to ensure high quality of the data bases that extend back to the early 1940's. Most of the current work of the center involves the DOE Health and Mortality Study, which is designed to examine the health and mortality history of DOE and its predecessor agency workers.

For information, contact:

Center for Epidemiological Research Medical \& Health Sciences Division Oak Ridge Associated Universities

P.O. Box 117

Oak Ridge, TN 37831-0117

(615) $576-3480$

\section{Experimental Reservoir Engineering Flow Facility}

Changes in simulated natural underground environments involving fluids are assessed in the facility. It provides technological information regarding nuclear waste disposal and other technologies. The facility will generate data for the design, operation and maintenance criteria necessary to examine the economic viability of a specific project. The information on underground environments also will be used to resolve environmental issues, such as water quality, geochemistry, ground subsidence and seismicity.

For information about this facility, contact:

Experimental Reservoir Engineering Flow Facility Pacific Northwest Laboratory

P.O. Box 999

Richland, WA 99352

(509) 375-3919

\section{Materials Characterization Center}

The center assesses the performance of nuclear waste materials in candidate waste systems required for all repository concepts that have been under consideration. Data are being provided for use in the evaluation, design, licensing and safety analysis of waste treatment processes, in the interim storage and transportation, and repository disposal of treated wastes. A set of shielded, research-quality analytical instruments is available for measurements on full-level, short-cooled highlevel waste materials to the same high degree of precision and accuracy previously only attainable on simulated nonradioactive waste materials. The instruments include a shielded X-ray diffraction (XRD) unit, an inductively coupled plasma emission spectrometer (ICP) and a scanning electron microscope (SEM). 
For information about this center, contact:

Materials Characterization Center

Pacific Northwest Laboratory

P.O. Box 999

Richland, WA 99352

(509) 376-9587

\section{Nuclear Operations Analysis Center (NOAC)}

The Nuclear Operations Analysis Center (NOAC) was established in 1981 to reflect the broadening and refocusing of the scope and activities of its two-decade-old predecessor, the Nuclear Safety Information Center. NOAC performs analysis tasks involving many aspects of nuclear power reactor operations and safety including analysis of nuclear power operating experience, generic case studies, plant operating assessment and risk assessments. NOAC has developed and designed a number of major data bases which it operates and maintains for the U.S. Nuclear Regulatory Commission. These data bases collect diverse types of information on nuclear power reactors from the construction phase through routine and off-normal operation. These data bases make extensive use of reactor-operator-submitted reports, such as the Licensee Event Reports (LERs). Services include consultation with staff specialists, retrospective searches of computerized files, technical inquiry service, access to the center for use of documents and the technical progress review publication entitled Nuclear Safety.

For information about this center, contact:

Nuclear Operations Analysis Center

Oak Ridge National Laboratory

P.O. Box 2009

Building 9201-3, Mail Stop 8065

Oak Ridge, TN 37831-8065

(615) 574-0377

\section{Radiation Emergency Assistance Center/Training Site (REAC/TS)}

The treatment center and training unit is available for rendering assistance in the management of health problems associated with radiation accidents and for formal teaching of medical and paramedical personnel. The major functions of REAC/ TS are: (1) to assist and provide medical and health physics support in the event of radiation-related emergencies by direct participation or consultation on a 24-hour basis; (2) to conduct epidemiologic studies on DOE radiation workers and radiation accident survivors; (3) to conduct radiation accident management training courses, exercises and drills for medical, paramedical and health physics personnel to meet the need for properly trained professionals in this area of occupational and emergency medicine; (4) to continue to develop and refine cytogenetic techniques for dose estimation of radiation accidents and exposure assessment from chemical toxicants in the industrial or general environment; and (5) to conduct research in radiation pathology, especially in the area of high-dose tissue injury. REAC/TS is committed to being available and ready to assist U.S. Government nuclear facilities and private nuclear powerplant and nuclear fuel processing plants in the event of nuclear emergencies. REAC/TS also maintains a registry of victims of radiation accidents. Presently, the system contains data on more than 136,615 individuals involved in 296 different events, including the Chernobyl experience.

For information about his center contact:

REAC/TS

Medical \& Health Sciences Division

Oak Ridge Associated Universities

P.O. Box 117

Oak Ridge, TN $37831-0117$

(615) $576-3131$

\section{Technical Software Programs: National Energy Software Center}

The National Energy Software Center (NESC) is DOE's software exchange and information center. NESC is operated by Argonne National Laboratory under a contract with OSTI. NESC collects, reviews, packages, maintains, announces and distributes a library of computer programs, models, system routines and data compilations developed by DOE and the NRC.

Computer programs and data compilations are obtained by NESC in various ways including the following:

- submission by DOE and NRC program divisions in compliance with guidelines and contract requirements;

- contribution by software development contractors; and

- exchange arrangements with other U.S. Government software centers and with foreign computer program libraries.

Any organization may register to participate in the NESC program. NESC members pay an annual registration fee that covers the cost of information services and recordkeeping. A registered site is entitled to receive two NESC software packages per year without charge, as well as bulletins and abstracts. Varying fees are charged for additional packages.

The software programs related to radioactive waste that are available at NESC are listed. For additional information, contact: 
Argonne National Laboratory

National Energy Software Center

9700 South Cass Avenue

Argonne, IL 60439

(708) $972-7250$

\section{Software Program Name: ACORN}

ACORN analyzes the input logical structure of a fault tree and provides data for a CalComp plot of the tree. The tree logic is specified as a set of FORTRAN statements, each defining a gate in terms of logical operations of the components input to it. The tree's physical structure is developed by assigning relative spatial coordinates to the logical relationships between a gate and its inputs. There are no fixed limits to the number of components in the tree. AND, $O R$, and INHIBIT gates are permitted, and basic events are drawn as diamonds, circles or houses. A descriptive label for each component (gate or basic event) can be written within a rectangle attached to the top of the component symbol.

NESC No.-9976

Language-FORTRANIV (99\%) and COMPASS (1\%)

\section{Software Program Name: AIRDOS-EPA}

AIRDOS-EPA estimates radionuclide concentrations in air; rates of deposition on ground surfaces; ground surface concentrations; intake rates via inhalation of air and ingestion of meat, milk and fresh vegetables; and radiation doses to man from airborne releases of radionuclides. The program may be run to estimate either the highest annual individual dose in the area or the annual population dose. For either option, output tables summarize doses by nuclide, exposure mode and organ. Using either a square or circular grid option, ground concentrations of radionuclides and intake rates by man are tabulated for selected environmental locations in the area surrounding the source. Working-level exposures for inhalation of radon-222 short-lived progeny are tabulated also.

\section{NESC No.-1001 \\ Language-FORTRAN IV}

\section{Software Program Name: ARRRG; Food}

ARRRG calculates radiation doses to humans for radionuclides released to bodies of water from which people might obtain fish, other aquatic foods or drinking water and in which they might fish, swim or boat. Food calculates radiation doses to humans from deposition on farm or garden soil and crops during either an atmospheric or water release of radionuclides. Deposition may be either directly from the air or from irrigation water. With both programs, doses may be calculated for either a maximally exposed individual or for a population group. Doses calculated are a 1-year dose and committed dose from 1 year of exposure. The exposure is usually considered as chronic; however, equations are included to calculate doses and dose commitment from acute, one-time exposure.

NESC No.-925

Language-FORTRAN

\section{Software Program Name: BWR-GALE}

BWR-GALE is a mathematical model for calculating the expected annual releases of radioactive material in gaseous and liquid effluents from boiling water reactors (BWRs). The calculations are based on data generated from operating reactors, field tests, laboratory tests and plant-specific design considerations incorporated to reduce the quantity of radioactive materials that may be released to the environment.

NESC No.-1080

Language-FORTRAN IV

\section{Software Program Name: CCC}

The numerical model CCC (conduction-convectionconsolidation) solves the heat and mass flow equations for a liquid-saturated, anisotropic, porous medium and computes one-dimensional (vertical) consolidation of the simulated systems. The model has been applied to problems in the fields of geothermal-reservior engineering, aquifer thermal-energy storage, well testing, radioactive waste isolation and in-situ coal combustion. The code has been validated against analytic solutions for fluid and heat flow, and against a field experiment for underground storage of hot water.

NESC No.-892

Language-FORTRAN IV

\section{Software Program Name: CHNSED}

CHNSED is an expanded model of hydrologic response of a watershed. It includes the simulation of trace contaminant transport through the watershed. Within the stream channel system, trace contaminant is transported in dissolved and absorbed form. CHNSED includes both SEDTRN, a model of sediment transport through a rectangular stream channel system, and the Wisconsin Hydrologic Transport Model, WHTM (NESC Abstract 808), a processes model. Processes considered in CHNSED include particulate mobilization (sheet erosion and overland transport) and dissolved contaminant transport (associated with runoff, interflow and base flow inputs to the channel system). An ion exchange submodel simulates the soil-contaminant-water interaction at the land surface; sediment transport and partitioning of trace contaminant between water and sediment in the channel system are also included. 
Following its entry into the channel system, dissolved contaminant transport is derived from flow routing algorithms of the WHTM. Routing of the absorbed fraction is controlled by sediment transport dynamics, which are governed by bedload and suspended load sediment transport.

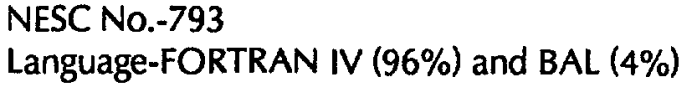

\section{Software Program Name: DARTAB}

$D A R T A B$ was written to provide tabulations of predicted impacts of radioactive airborne effluents by combining information on environmental concentrations with dosimetric and health effects data. Radionuclide-intake rates and dosimetric- and health-effects information are used to calculate health impacts. DARTAB is independent of both the environmental transport code used to derive estimates of environmental concentrations and the origin of the dosimetricand health-effects data. Options are included to permit the user to request tabulations by various topics (e.g., cancer site, exposure pathway, etc.) to facilitate characterization of the human-health impacts of the effluents. The output tables can be: (1) summary tables, which give summaries by pathways, organs and radionuclides for dose and health effects; (2) detailed tables, which tabulate values for an average or selected individual or collective population; or (3) location tables, which tabulate the selected value for the entire environmental exposure grid.

NESC No.-9874

Language-FORTRAN IV

\section{Software Program Name: DEISCODES}

DEISCODES, (the Draft Environmental Impact Statement CODES) are five separate FORTRAN codes used to perform the analysis in the Draft Environmental Impact Statement written to support 10 CFR 61, "Licensing Requirements for Land Disposal of Radioactive Waste." The five codes are named OPTIONS, GRWATER, INTRUDE, INVERSW and INVERSI. They are written specifically for calculating the impacts of the new requirements. GRWATER calculates impacts of ground water migration to an off-site well, to an inadvertent intruder's well and to a surface discharge. The INTRUDE code calculates impact to an inadvertent intruder. The INVERSW and INVERSI codes calculate the radionuclide concentrations that, if exceeded, would exceed the dose limitations proposed in the new requirements for the ground water scenarios and the inadvertent-intruder scenarios, respectively.

NESC No.-9901

Language-FORTRAN IV

\section{Software Program Name: DIGMAN}

DIGMAN was developed to illustrate the complexities in sampling a commercial low-level radioactive waste site for spills or migration. Monitoring for both purposes is required by 10 CFR Part 61. DIGMAN tests a site manager's ability to locate a contaminated area and to determine its areal extent. In the DIGMAN scenario, it is assumed that contamination is present. By sampling the site, the extent of the contamination must be determined and a decision made as to whether the contaminant has migrated off-site. The site manager (player) is given the prior knowledge that a spill has occurred and subsequently migrated through or over the soil surface. In addition, the location is given for one point where some contamination is known to exist. Such information may or may not be available at actual sites. The player is allowed to take a maximum of 45 samples. The DIGMAN waste site provides the player with 1600 possible sampling sites, which is far fewer than would actually be available. Thus, the situations depicted by DIGMAN are simplest of the myriad of possible scenarios which might be faced by a site manager. Several different scenarios relating to sampling and costs can be used in playing DIGMAN.

\section{NESC No.-9742}

Language-BASIC

\section{Software Program name: DOT-BPMD}

$D O T-B P M D$ is a general-purpose, finite-element, heattransfer program used to predict thermal environments. The code considers linear and nonlinear transient or steady-state heat conduction in two-dimensional planar or axisymmetric representations of structures. Capabilities are provided for modeling anisotropic heterogeneous materials with temperature-dependent thermal properties and timedependent temperature-, heat flux-, convection- and radiation-boundary conditions, together with time-dependent internal heat generation. DOT-BPMD may be used in the evaluation of steady-state geothermal gradients as well as in the transient heat-conduction analysis of repository and waste package systems.

\section{NESC No.-9833 \\ Language-FORTRAN IV}

\section{Software Program Name: EQ3, EQ6}

EQ3 computes, from user-specified analytical data, the distribution of chemical species (ions, neutral species, ion pairs and complexes) in an aqueous solution. The aqueoussolution model generated by EQ3, which specifies the concentration and thermodynamic activity of each species occurring in the chemical system, is used as a starting point 
for the EQ6 reaction path calculations. EQ6 computes reaction-path models involving changes in temperature and pressure and/or irreversible reaction of the fluid with reactants (rocks, minerals and gases). Together, they can be used in both far-field and near-field performance assessments. They maybe used to compute distribution coefficients and solubility limits of radionuclides in the repository. The results of these calculations will then interface with transport codes, such as SWENT (NESC 9811), or a waste package performance assessment code, such as WAPPA (NESC 9673).

NESC No.-9661

Language-FORTRAN IV

\section{Software Program Name: FE3DGW}

FE3DGW (Finite Element 3-Dimensional Ground Water) analyzes flow through large, multilayered, ground water systems. The code has the capability to model noncontinuous as well as continuous layers, time-dependent and constant sources/sinks and transient as well as steady-state flow. The program can be used to support site characterization, evaluate ground water flow rates and estimate travel path and time in regional and local ground water systems.

NESC No.-9722

Language-FORTRAN

\section{Software Program Name: FEMWATER 1, FEMWASTE 1}

The FEMWATER 1 and FEMWASTE 1 programs model water flow and waste transport, respectively, through saturatedunsaturated porous media. The special features of these programs are their flexibility and versatility in modeling realworld problems.

NESC No.-9902
Language-FORTRAN IV

\section{Software Program Name: FFSM}

FFSM (Far Field State Model) predicts the approximate geologic and climatic state of a site for a nuclear waste repository over relatively long periods of time. The purpose of FFSM is to represent quantitatively certain events and processes that could alter the effectiveness of one or more natural barriers in a waste-isolation system. The barriers treated by the model are primarily components of the geologic environment surrounding the repository, although biosphere components (e.g., climate parameters) that could affect the impact of radionuclide releases are also considered. These components are treated outside the realm of wastes or repository-induced effects, which is indicated by use of the term "far-field." The model treats both natural and maninduced changes in these barriers within a probabilistic framework, and it accounts for cumulative and interactive effects of multiple phenomena. Fifteen submodels are included in FFSM to account for phenomena that may be of importance individually or in combination in evaluating sites for repositories. These submodels include: undetected features, climate, worldwide glaciation, local glaciation, folding, salt dispersion, magmatic events, faulting, biosphere state, regional deformation, geomorphic processes, dissolution fronts, localized dissolution (breccia pipes), solution mining and drilling. FFSM can be used in both a deterministic mode, to evaluate interactions or to calculate point values, and a probabilistic mode, to make statistical estimates of future changes. In the probabilistic mode, Monte Carlo simulation is used to generate output probabilities, based on use-supplied input, largely in the form of probability density functions for variable or uncertain parameters. FFSM is based on a simulation methodology used previously in the GSM program (NESC 9845),

NESC No.-9844

Language-ANSI FORTRAN X3.9-1978

\section{Software Program Name: FIRAC}

FIRAC predicts fire-induced flows, thermal and material transport and radioactive and nonradioactive source terms in a ventilation system. It is designed to predict the radioactive and nonradioactive source terms that lead to gas-dynamic, material-transport and heat-transfer transients. FIRAC's capabilities are directed toward nuclear fuel cycle facilities and the primary release pathway - the ventilation system. However, it is applicable to other facilities and can be used to model other airflow pathways within a structure. The basic material transport capability of FIRAC includes estimates of entrainment, convection, deposition and filtration of material. The interrelated effects of filter plugging, heat transfer and gas dynamics are also simulated. A ventilation system model includes elements such as filters, dampers, ducts and blowers connected at nodal points to form networks. A zone-type compartment fire model is incorporated to simulate fire-induced transients within a facility.

NESC No.-10922

Language-FORTRAN

\section{Software Program Name: FTRANS}

FTRANS(Fractured flow and Transport of RAdioNuclideS) is a two-dimensional finite-element code designed to simulate ground water flow and transport of radioactive nuclides in a fractured porous return medium. FTRANS takes into account fluid interactions between the fractures and porous matrix blocks, advective-dispersive transport in the fractures and diffusion in the porous matrix blocks and chain reactions 
of radionuclide components. It has the capability to model the fractured system using either the dual-porosity or the discrete-fracture modeling approach or a combination of both. FTRANS can be used to perform two-dimensional near-field or far-field predictive analyses of ground water flow and to perform risk assessments of radionuclide transport from nuclear waste repository subsystems to the biosphere.

Because of its general flexibility, it is particularly suited to the study of flow and transport processes around repository return subsystems.

\section{NESC No.-9860 \\ Language-FORTRAN IV}

\section{Software Program Name: GASPAR}

GASPAR implements the air-released dose models of the NRC Regulatory Guide 1.109 for noble gases (semi-infinite plume only) and the radioiodine and particulate emissions (specifically 1.109-10 through 1.109-13 and a portion of 1.109-14). GASPAR computes both population (ALARA-As Low As Reasonably Achievable and NEPA-National Environmental Policy Act) and individual doses. Site data, meteorological data, radionuclide-release source terms and location meteorological data for selected individuals are specified as input data. The site data include population data and milk, meat and vegetation production. The meteorological data include dispersion $X / Q, X / Q$ decayed, $X / Q$ decayed and depleted, and deposition. Population doses, individual doses and cost benefittables are calculated.

\author{
NESC No.-963 \\ Language-FORTRAN IV (98\%) \\ and Assembly language (2\%)
}

\section{Software Program Name: GEOTHER}

GEOTHER is a three-dimensional, geothermal reservoir simulation code. The model describes heat transport and flow of a single component, two-phase fluid in porous media. It is based on the continuity equations for steam and water, which are reduced to two nonlinear partial differential equations in which the dependent variables are fluid pressure and enthalpy. These equations, describing three-dimensional effects, are approximated using finite-difference methods and are solved using an iterative technique. The nonlinear coefficients are calculated using Newton-Raphson iteration, and an option is provided for using either upstream or midpoint weighing on the mobility terms. The model can be used to investigate temperature and fluid pressure changes in response to thermal loading by waste materials.

\section{Software Program Name: GSM}

GSM (Geologic Simulation Model) is a Monte Carlo simulation program for tracking the future evolution of a repository site over periods of up to several million years. Phenomena included in the model that potentially can affect the site over such periods are climatic changes, glaciation, deformation, geomorphicevents, magmatic events, meteorite impact, sea-level fluctuations, shaft-seal failure, basement faulting and undetected features. Interrelationships among phenomena are modeled, and the effects of changes on ground water flow are followed using a simplified network model of the ground water system in a two-dimensional cross-section of the study area. The model is specific to a potential repository site in the Pasco Basin area of the Columbia Plateau. The Monte Carlo simulation is based on random sampling from a relatively large number of usersupplied probability density functions. These functions represent phenomena characteristics or probability of occurrence and may be derived by a variety of methods, ranging from statistical analysis to expert opinion. The ground water portion of the code is two-dimensional and is based on a specific conceptualization of the hydrology in the region surrounding the Pasco Basin. The probabilistic nature of the model enables it to be used to evaluate whether a potential site meets any probabilistic regulatory standards such as those that have been issued by the Environmental Protection Agency.

\section{NESC No-9845 \\ Language-ANSI FORTRAN X3.9-1978}

\section{Software Program Name: GETOUT}

GETOUT is a set of four FORTRAN programs and associated subroutines developed as an aid to investigate the migration of radionuclide chains from an underground source. The model to be analyzed is an underground nuclear waste disposal site and a uniform one-dimensional soil column that connects the site with a surface water body. At an arbitrary time after the waste is deposited, the radioactive material is released to an underground aquifer that flows at constant velocity directly through the soil column into the surface water body. The program takes into account the complications introduced by the radioactive decay of firstorder chains to produce other species which have different absorption characteristics and, in turn, decay at different rates.

NESC No.-887

Language-FORTRAN

NESC No.-9834

Language-FORTRAN IV 


\section{Software Program Name: HERMES}

The HERMES model calculates the regional radionuclide releases and radiation dose to the populace in a given year arising from the operation of nuclear facilities to meet electrical-generation demands within a given study region.

NESC No.-527

Language-FORTRAN IV and SLEUTH

\section{Software Program Name: LAYFLO}

LAYFLO predicts the one-dimensional convective-dispersive and nondispersive transport of a three-member decay chain in a stratified geologic medium. The dispersive solution is restricted to six layers, while the nondispersive solution can handle any number of layers. The accuracy of LAYFLO was tested on a selected number of problems for which analytical solutions or experimental data were available.

NESC No.-R1038

Language-FORTRAN 77

\section{Software Program Name: LADTAP2}

LADTAP2 performs environmental-dose analyses for releases of liquid effluents from light-water nuclear powerplants into surface waters during routineoperation. The analyses estimate radiation doses to individuals, population groups and biota from ingestion (aquatic foods, water and terrestrial irrigated foods) and external exposure (shoreline, swimming and boating) pathways. The calculated doses provide information for National Environmental Policy Act (NEPA) evaluations and for determining compliance with Appendix 1 of $10 \mathrm{CFR}$ 50 (the "ALARA" philosophy).

NESC No.-992

Language-FORTRAN 77

\section{Software Program Name: MATLOC}

MATLOC is a nonlinear, transient, two-dimensional (planar and axisymmetric), thermal-stress, finite-element code designed to determine the deformation within a fractured rock mass. The rock mass is modeled as a nonlinear anisotropic elastic material which can exhibit stressdependent bilinear locking behavior. The numerical solution of the nonlinear equilibrium equations is performed using the incremental tangential stiffness method in which the material stiffness matrices are continually updated. MATLOC is primarily suited for use in room and canister scale studies of the excavation, operational and short-term post-closure processes for sites within geological media which do not exhibit significant viscoelastic (creep) phenomena or in situations where the viscoelastic behavior can be ignored. Three-dimensional deformations and discontinuous displacements across open fractures and faults cannot be modeled. MATLOC can solve a problem with a maximum of 400 elements with up to 1000 nodes, of which 200 may be fixed.

\author{
NESC No.-9851 \\ Language-FORTRAN IV
}

\section{Software Program Name: MESOI2.0}

MESOI Version 2.0 is an interactive Lagrangian puff model for estimating the transport, diffusion, deposition and decay of effluents released to the atmosphere. The model is capable of treating simultaneous releases from as many as four release points, which may be either at elevated locations or at ground level. The puffs are advected by a horizontal wind field that is defined in three dimensions. The wind field may be adjusted for expected topographic effects. The concentration distribution within the puffs is initially assumed to be Gaussian in the horizontal and vertical directions. However, the vertical concentration distribution is modified by assuming reflection at the ground and the top of the atmospheric mixing layer. Material is deposited on the surface using a source depletion, dry-deposition model and a washout-coefficient model. The model also treats the decay of a primary effluent species and the ingrowth and decay of a single daughter species using a first-order decay process.

$$
\begin{aligned}
& \text { NESC No.-9862 } \\
& \text { Language-ANS FORTRAN X3.9-1977, } \\
& \text { with VAX extensions }
\end{aligned}
$$

\section{Software Program Name: $M M T$}

MMT (Multicomponent Mass Transport) solves the onedimensional equation for transport of radionuclides in a ground water system with uniform velocity and transport properties. The purpose of the code is to evaluate radionuclide-release rates from the site subsystem. MMT treats convective transport, sorption-desorption effects and hydrodynamic dispersion. Sorption and desorption of radionuclides are taken into account by application of retardation factors which are spatially uniform and derived from bulk rock properties and average geochemical data. Dispersion along the direction of flow (forward and backward) is also taken into account. Because the code solves only the one-dimensional transport equation, dispersion transverse to the direction of the flow is not evaluated. A discreteparcel-random-walk (DPRW) approach is used to solve the coupled equations. This numerical technique is inherently stable and minimizes computational errors that lead to apparent mass nonconservation.

NESC No.-9853

Language-FORTRAN 77 (FTN5) 


\section{Software Program Name: NETFLO}

NETFLO simulates three-dimensional, ground water flow in a heterogeneous medium idealized as a flow through an equivalent network of series and parallel flow members under steady-state flow conditions. The algorithm is based on the application of Darcy's law along each member and conservation of mass at each node. NETFLO determines the pressure at all nodes, and velocities and fluxes in all members, for all possible flow paths from a repository node to the discharge node, and the pertinent mean flow and transport characteristics along each path, for use as input to a onedimensional nuclide-transport program like GETOUT.

NESC No.-9831

Language-FORTRAN IV

\section{Software Program Name: NUTRAN}

NUTRAN is a system of four computer programs for calculating the dose to humans from radionuclides carried out of deep geologic nuclear waste repositories by ground water. NUTRAN is composed of the FORTRAN programs ORIGEN1 and BIODOSE - and the PLI programs - WASTE and PLOT. ORIGEN1, developed by Oak Ridge National Laboratory, generates an inventory of radionuclides as a function of time; BIODOSE computes the doses to humans which result from any releases of radioactivity into the biosphere. WASTE models the release of radionuclides from a repository and their transport in the subsurface, and PLOT combines the results of BIODOSE and WASTE - dose per $M W e-y r$ released and releases in units of Mwe-yr of waste to obtain doses and generate dose plots. The ORICEN1 program developed by ORNL is not included.

NESC No. 9888

Language-FORTRAN IV (50\%) and PLI (50\%)

\section{Software Program Name: ODMOD}

$O D M O D$ is a transport model that predicts the coupled movement of water and trace contaminants through a layered and unsaturated soil-moisture zone. In order to achieve computation speeds suitable for watershed implementations, moisture properties are approximated as exponential functions of pressure head, and lateral flows are treated as sinks in a basically vertical one-dimensional analysis. In addition, only advection by the Darcy-flow velocities and linear absorption by the soil-matrix are considered in depicting movement of the trace contaminant.

NESC No.-789

Language-FORTRAN IV (97\%) and BAL (3\%)

\section{Software Program Name: PABLM}

$P A B L M$ calculates internal radiation doses to man from radionuclides in food products and external radiation doses from radionuclides in the environment. Radiation doses from radionuclides in the environment may be calculated from deposition on the soil or plants during an atmospheric or liquid release or from exposure to residual radionuclides after the releases have ended. Radioactive decay is considered during the release, after deposition and during holdup of food after harvest. The radiation dose models consider exposure to radionuclides deposited on the ground or crops from contaminated air or irrigation water, radionuclides in contaminated drinking water, aquatic foods raised in contaminated water and radionuclides in bodies of water and sediments where people might fish, boat or swim. For vegetation, the radiation dose model considers both direct deposition and uptake through roots. Doses maybe calculated for either a maximally exposed individual or for a population group. The program is designed to calculate accumulated radiation doses from the chronic ingestion of food products that contain radionuclides and doses from the external exposure to radionuclides in the environment. A first-year committed dose is calculated as well as an integrated dose for a selected number of years.

NESC No.-926

Language-FORTRAN

\section{Software Program Name: PFPL}

PFPL is an interactive transport and diffusion program developed for real-time calculation of the location and concentration of toxic or radioactive materials during an accidental release. Deposition calculations are included.

NESC No. -9800

Language-FORTRAN 77

\section{Software Program Name: PHREEQE}

PHREEQE is designed to model geochemical reactions. Based on an ion-pairing aqueous model, PHREEQE can calculate $\mathrm{pH}$, redox potential and mass transfer as a function of reaction progress. It can be used to describe geochemical processes for both far-field and near-field performance assessment and to evaluate data acquisition needs and test data. It can also calculate the composition of solutions in equilibrium with multiple phases. The data base, including elements, aqueous species and mineral phases, is independent of the program and is completely user-definable. PHREEQE requires thermodynamic data for each solid, gaseous or dissolved chemical species being modeled. The two data bases, PREPHR and DEQPAK7, supplied with PHREEQE are 
for testing purposes only and should not be applied to real problems without first being carefully examined.

NESC No.-9674

Language-FORTRAN IV

\section{Software Program name: PLANMAP REV1}

PLANMAPREV1, which consists of two interactive programs, PLAN-IO and PLAN-PLOT, is used to plot geochemical data. Data are supplied by keyboard entry and can be listed, edited and plotted. The input data consist of geochemical sample assay values and the coordinates that describe the locations of these samples. The output consists primarily of a plot that represents a map showing the data for one selected element or assay. The data may be modified in various ways, such as editing, adjusting assay value according to silicate content of sample or the mathematical function mapping. Various symbols may be selected to represent the sample locations on the plot. When producing the plot, the user interactively specifies parameters such as plot size, units and scale factors. The data for one problem area may be saved and another retrieved, all under program control. Map section corner coordinates may be included as input data and either a keyboard or line printer listing of the data may be obtained, if desired.

NESC No.-981

Language-FORTRAN $\vee(97 \%)$ and

Assembly Language (3\%)

\section{Software Program Name: PWR-GALE}

PWR-GALE calculates the expected annual releases of radioactive materials in gaseous and liquid effluents from pressurized light water reactors (PWRs). The calculations are based on data generated from operating reactors, field and laboratory tests and plant-specific considerations incorporated to reduce the quantity of radioactive materials that may be released to the environment during normal operation, including anticipated operational occurrences.

NESC No.-1081

Language-FORTRAN IV

\section{Software Program Name: RABFIN, PARTS}

RABFIN calculates technical specification dose parameters for the noble gas portion of gaseous effluents from nuclear powerplants. Finite noble gas doses from short-term (purge) releases are calculated; the output includes the finite plume air, total body and skin doses. Corresponding dose quantities computed assuming semi-infinite exposure geometry are also presented for comparison purposes. PARTS calculates technical specification dose parameters for iodine and particulate portions of gaseous effluents.

\author{
NESC No.-998 \\ Language-FORTRAN $V$
}

\section{Software Program Name: RAFT}

RAFT calculates release quantities and a risk measure based on the product of probability and release quantity for cut sets of a fault tree modeling the accidental release of radioactive material from a nuclear-fuel-cycle facility. Cut sets and their probabilities are supplied as input to RAFT from an external fault-tree analysis program (e.g., MFAULT, NESC 9975). Using the total inventory available of radioactive material, along with release fractions for each event in a cut set, release terms are calculated for each cut set. Each release term is multiplied by the cut set probability, yielding the cut-set risk measure. RAFT orders the dominant cut sets on the risk measure. The total risk measure of processed cut sets and their fractional contributions are supplied as output. Input options are available to eliminate redundant cut sets, apply threshold on cut-set probability and risk, and control the total number of cut sets produced. Hash addressing is used to remove redundant cut sets from the analysis.

NESC No.-9974

Language-FORTRAN IV

\section{Software Program Name: RATAF}

RATAF calculates the consequences of radioactive-liquid tank failures. In each of the processing systems considered, RATAF can calculate the tank isotopic concentrations in either the collector tank or the evaporator-bottoms tank.

NESC No.-1004

Language-FORTRAN IV

\section{Software Program name: RECON}

RECON is designed to estimate costs of mined geologic repositories based on parametric input data. Input parameters describe facilities, construction times, shafts, mine design, emplacement limitations, waste flows available for disposal, waste processing parameters (labor, materials, utility and equipment requirements), facility construction costs and unit labor, materials utility and equipment costs. Using this information, RECON determines the facility requirements for receiving, packaging, transporting and emplacing the wastes. Based on the facility requirements, RECON calculates labor, material and equipment requirements. Labor requirements are calculated in shifts based on available working days. From the shifts and days worked, utility 
requirements are calculated. Equipment replacement requirements are calculated based on equipment life (stated in years or units processed) and processing rates. All of the above requirements are calculated year-by-year for each of up to 10 waste types, thereby simulating actual repository operations.

NESC No.-9760

Language-FORTRAN ASCI I

\section{Software Program Name: SALT4}

SALT4 is a two-dimensional, analytical/displacementdiscontinuity code designed to evaluate temperatures, deformation and stresses associated with underground disposal of radioactive waste in bedded salt. SALT4 takes into account viscoelastic behavior in the pillars adjacent to excavations, transversely isotropic elastic moduli such as those exhibited by bedded or stratified rock, and excavation sequence. SALT4 can be used for parameter sensitivity analyses of two-dimensional, repository-scale, thermal and thermomechanical response in bedded salt during the excavation, operational, and post-closure phases. It is especially useful in evaluating alternative patterns and sequences of excavation or waste-canister placement. In $S A L T 4$, the temperature distribution and associated thermal stresses are approximated by analytic solutions for a line heat source in an elastic medium. The mechanical effects due to excavation of the repository openings are treated by the displacement-discontinuity method. Although SALT4 was designed for analysis of bedded salt, it is also applicable to crystalline rock if the creep calculation is suppressed. The main disadvantage of SALT4 is that some of the assumptions made (i.e., temperature-independent material properties) render it unsuitable for canister-scale analysis or analysis of lateral deformation of the pillars.

NESC No.-9849

Language-FORTRAN IV

\section{Software Program Name: SECTION.REV1}

SECTION.REV1, which consists of two interactive programs, $S E C-I O$ and SEC-PLOT, provides plots of core sample geochemical data for any or all drill holes in a given area projected onto any predetermined section plane. Plot size is user-defined by keyboard input. Holes are plotted in cross section as straight lines defined by collar coordinates, bearing angle, dip angle and length. SECTION.REV1 is applicable to small problem areas with relatively short drill holes that are approximately straight. The data for one problem area may be saved and another retrieved, all within program control.

NESC No.-977

Language-FORTRAN IV

\section{Software Program Name: SPXCPL}

SPXCPL is a two-dimensional modeling program of selfpotential effects from cross-coupled fluid and heat flow. The geological structure is two-dimensional but the sources can be either finite line sources or point sources. The SelfPotential (SP) method is based on the measurement of naturally occurring potential differences generated mainly by electrochemical, electrokinetic and thermoelectric sources. The SP method of geophysical interpretation is used in geothermal exploration, earthquake-related phenomena and in other engineering applications.

$$
\begin{aligned}
& \text { NESC No.-985 } \\
& \text { Language-FORTRAN IV }
\end{aligned}
$$

\section{Software Program Name: STAFAN}

STAFAN (STress And Flow ANalysis) is a two-dimensional, finite-element code designed to model fluid flow and the interaction of fluid pressure and mechanical stresses in a fractured rock surrounding a nuclear waste repository. STAFAN considers flow behavior of a deformable fractured system with fracture-porous matrix interactions, the coupling effects of fluid pressure and mechanical stresses in a medium containing discrete joints, and the inelastic response of the individual joints of the rock mass subject to the combined fluid pressure and mechanical loading. STAFAN does not presently contain thermal coupling, and it is unable to simulate inelastic deformation of the rock mass and variably saturated or two-phase flow in the fractured porous medium system. STAFAN is particularly suited to application in the study of flow and mechanical deformation processes around repository subsystems.

NESC No.-9850

Language-FORTRAN IV

\section{Software Program Name: STFLO}

STFLO is a simple linear, finite-element code designed to simulate two-dimensional (areal or vertical) plane or axisymmetric ground water flow in porous media. STFLO handles inhomogeneous anisotropic material properties, confined and semiconfined (leaky) aquifers, distributed or point sources and specified heads or flux boundary conditions. A combination of quadrilateral and triangular elements may be used for the discretization of the flow domain. The program solves the general partial differential equation which governs steady-state fluid flow in a two-dimensional anisotropic and heterogeneous material. The primary application of STFLO is to estimate the rate of ground water flow through a waste package by simulating rock. STFLO output consists of hydraulic heads at the nodes and velocities at the center of each finite element. STFLO is simple and 
inexpensive to apply. Its application is limited to isothermal, steady-state flow in a porous medium.

NESC No.-9852
Language-FORTRAN IV

\section{Software Program name: SWENT}

SWENT (Simulator for Water, Energy and Nuclide Transport) simulates the transient transport of fluid, heat, an inert component and any number of radionuclides through a heterogeneous geologic medium either in three dimensional or radial geometries. The first three transport processes are coupled by the fluid properties of density and viscosity. The velocity field is derived from the solution of the coupled processes and used in the fourth process. Since radionuclides are present in trace quantities only, this process is not coupled to the first three. Aquifer porosity is treated as a function of pressure. The resulting system of nonlinear partial differential equations is solved by finite-difference approximations, suitable linearization schemes and an iterative technique to reduce the errors that arise in linearization. Options are available which permit simulation of any one of the individual processes or coupled combinations of the processes. A special option is available to treat steady-state fluid flow with transient radionuclide transport. SWENT offers a wide choice in the specification of boundary conditions. The program can be used in a wide variety of ground water applications.

NESC No.-9811

Language-FORTRAN IV

\section{Software Program Name: SWIFT}

SWIFT solves the coupled or individual equations governing fluid flow, heat transport, brine displacement and radionuclide displacement in geologic media. Fluid flow may be transient or steady-state. One, two or three dimensions are available and transport of radionuclide chains is possible.

NESC No.-973

Language-FORTRAN IV

\section{Software Program Name: THORIN, INTERP}

The pair of programs - THORIN, INTERP - is used to determine the subsurface geology of large-diameter emplacement holes to ensure the absence of unacceptable features that could compromise the containment of radioactive gases. The programs calculate the gravimetric density of three-dimensional structures by using contour maps of subsurface boundaries between media of different densities. These maps, called isopach maps, show the thickness of material overlying subsurface geologic units. The map contour lines are digitized data input to INTERP, which constructs a function to interpolate the given data and then evaluates the function to create a rectangular grid of prisms. These grid data represent the structure surrounding the borehole and are used by THORIN, which calculates the gravity caused by that grid and the gravimetric densities at each depth point. The local structural geology is inferred by comparing measured and calculated gravimetric density to density from a gamma-gamma density log.

NESC No.-9604

Language-FORTRAN

\section{Software Program Name: TOUGH}

TOUGH (Transport of Unsaturated Ground water and Heat) is a multi-dimensional numerical model for simulating the coupled transport of water, vapor, air and heat in porous and fractured media. The program provides options for specifying injection or withdrawal of heat and fluids. Although primarily designed for studies of high-level nuclear waste isolation in partially saturated geological media, it should also be useful for a wider range of problems in heat and moisture transfer, and in the drying of porous materials. For example, geothermal reservoir simulation problems can be handled simply by setting the air mass function equal to zero input. The TOUGH simulator was developed for problems involving strongly heat-driven flow. To describe these phenomena, a multi-phase approach to fluid and heat flow is used, which fully accounts for the movement of gaseous and liquid phases, their transport of latent and sensible heat and phase transitions between liquid and vapor. TOUCH takes account of fluid flow in both liquid and gaseous phases occurring under pressure, viscous and gravity forces according to Darcy's law. Interference between the phases is represented by means of relative permeability functions. The code handles binary, but not Knudsen, diffusion in the gas phase and capillary and phase adsorption effects for the liquid phase. Heat transport occurs by means of conduction with thermal conductivity dependent on water saturation, convection and binary diffusion, which includes both sensible and latent heat.

$$
\begin{aligned}
& \text { NESC No.-1098 } \\
& \text { Language-FORTRAN } 77
\end{aligned}
$$

\section{Software Program Name: TOXRISK}

TOXRISK is an interactive program developed to aid in the evaluation of nuclear powerplant control room habitability in the event of a nearby toxic material release. The program uses a model which is consistent with the approach described in the NRC Regulatory Guide 1.78. Release of the gas is treated as an initial puff followed by a continuous plume. The relative proportions of these as well as the plume-release 
rate are supplied by the user. Transport of the gas is modeled as a Gaussian distribution and occurs through the action of a constant velocity, constant direction wind. Dispersion or diffusion of the gas during transport is described by modified Pasquill-Gifford dispersion coefficients. Great flexibility is afforded the user in specifying the release description, meteorological conditions, relative geometry of the accident and plant, and the plant ventilation system characteristics.

NESC No. -9710

Language-FORTRAN 5

\section{Software Program Name: TRIPM}

TRIPM is a mathematical model designed to predict the transport of radionuclides and their decay products in a saturate-unsaturated vertical plane of a phreatic aquifer under isothermal conditions. The model is composed of two modules: the first calculates the pressure distribution in the domain of interest, enabling computation of the velocities and soil moisture; the second calculates the migration of the various species by taking into account the major processes associated with the transport phenomena of a dissolved substance in porous media (i.e., advection mechanical dispersion, molecular diffusion, radioactive decay and sorption). The influence of soil-water $\mathrm{pH}$ on the distribution coefficient is also considered. The first module may be used independently of the second.

NESC No.-1028

Language-FORTRAN IV

\section{Software Program Name: UCBNE10.2}

UCBNE10.2 calculates the one-dimensional migration of radionuclides in a three-member chain in a geological medium saturated with ground water. The geological medium is considered to be a composite material, which consists of solid and liquid phases, and the transport of radionuclides along the interface between the two phases is neglected. The various possible release modes which can be considered include the band, the step, the preferential release and the exponential.

NESC. No.-9668

Language-FORTRAN 77

\section{Software Program Name: UCBNE25}

UCBNE25 estimates the maximum concentration of nuclides occurring during the migration of three-member radionuclide chains in geologic media without axial dispersion. Unlike other migration codes, the release rate in UCBNE25 is the independent variable, and time is the dependent variable. The extrema in concentrations are determined without having to calculate the entire concentration history. The program assumes one-dimensional water transport and sorption equilibrium for the nuclides in the soil and in the water. The water velocity is held constant, and the leach times are smaller than the half-lives of the nuclides involved. UCBNE25 calculates for each nuclide the time of the maxima at a specified position, the maximum dimensionless concentration, the corresponding water dilution rate and the contamination time for that position. The closed form solutions can be easily checked by hand, making it a useful calibration tool for other codes.

NESC No.-9667

Language-FORTRAN (CDC FTN5)

\section{Software Program Name: UDAD}

$U D A D$ (the Uranium Dispersion and Dosimetry program) provides estimates of potential radiation exposure to individuals and to the general population in the vicinity of a uranium-processing facility such as a uranium mine or mill. Only transport through the air is considered. Exposure results from inhalation, external irradiation from airborne and ground-deposited activity and ingestion of foodstuffs. Individual dose commitments, population dose commitments and environmental dose commitments are computed. The program was developed for application to uranium mining and milling; however, it may be applied to dispersion of any other pollutant.

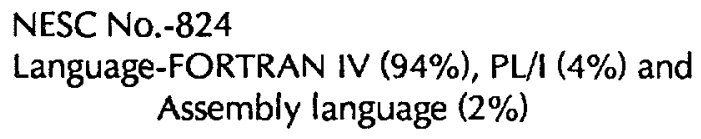

\section{Software Program Name: VISCOr}

VISCOT is a nonlinear, transient, thermal-stress, finiteelement program designed to determine the viscoelastic, viscoplastic or elastoplastic deformation of a rock mass due to mechanical and thermal loading. The numerical solution of the nonlinear incremental equilibrium equations is performed by using an explicit Euler time-stepping scheme. The rockmass may be modeled as a viscoplastic orviscoelastic material. The viscoplastic material model can be described by a Tresca, von Mises, Drucker-Prager or Mohr-Coulomb yield criteria (with or without strain hardening) with an associated flow rule which can be a power or an exponential law. The viscoelastic material model is a temperature- and stress-dependent law which has been developed by Pfeifle, Mellegard and Senseny specifically for salt rock masses. Sitespecific parameters for this creep law at the Richton, Permian, Paradox and Vacherie salt sites are given in the ONWI-314 report.

NESC No.-9846

Language-FORTRAN IV 


\section{Software Program Name: WAPPA}

WAPPA (the WAste Package Performance Assessment program) is intended to serve as a tool for evaluating both the relative and the absolute performance of waste-package designamong concepts, for guiding or selecting a preliminary design among conceptual designs, and for support of licensing activities. WAPPA is a barrier degradation code for a nuclear waste package in a geologic repository. The WAPPA model includes five distinct degradation process models (radiation, thermal, mechanical, corrosion and leaching), which are driven internally by waste decay and externally by repository stress and fluids. The modeling approach is barrier-integrated and process-sequential, allowing modifications of the entire waste package by the sequential operation of five process models within each time-step. The process models are coupled at the system level via state and coupling variables. The penetration of water into the waste package and its effects on the barriers it contacts are tracked radially inwards. The WAPPA model describes and predicts the temporal and spatial extent of the loss of containment capability for each barrier and for the entire waste package, on any time scale up to one million years after isolation.

NESC No.-9673

Language-FORTRAN 77

\section{Software Program Name: WHTM and OPTRM}

WHTM is the Wisconsin Hydrologic Transport Model that treats the movement of water and trace amounts of chemicals from the place and time of introduction onto the land area segments of a watershed, through these segment vertical profiles to the water table or laterally to streams, and through thestream channel network to the watershed outfall. Overland and stream flow are governed by the Chezy-Manning equation. Trace chemical transport is represented by an ionexchange model that uses a single distribution coefficient $K(d)$ for each chemical species. Operation of the program requires historical hourly precipitation data and daily or monthly climatological data in addition to the parameters used to describe the watershed. OPTRM is used to determine an optimal set of model parameters for the WHTM. An optimal set of parameters is defined as that set that gives in a mathematical sense the best simulation (i.e., provides the best match on either a monthly or daily basis between observed outflows and simulated outflows.) The term outflow applies here to either water or trace contaminant values.

NESC No.-WHTM:808

OPTRM:794

Language-WHTM: FORTRAN IV (96\%) and

Assembly Language (4\%)

OPTRM: FORTRAN IV and BAL (4\%)

\section{Software Program Name: XOQDOQ}

$X O Q D O Q$ was designed for meteorological evaluation of continuous and anticipated intermittent releases from commercial nuclear power reactors. It calculates annual relative effluent concentrations and average relative deposition values at locations specified by the user and at various standard radial distances and segments for downwind sectors. It also calculates these values at the specified locations for anticipated intermittent (e.g. containment or purge) releases, which occur during routine operation. The program computes an effective plume height that accounts for physical release height, aerodynamic downwash, plume rise and terrain features. The user may optionally select additional plume dispersion due to building wakes, plume depletion via dry deposition and plume radioactive decay or specify adjustments to represent non-straight line trajectories (recirculation or stagnation).

NESC No.-964

Language-FORTRAN 77 


\section{Congressional Committees and Subcommittees}

The U.S. Senate and House of Representatives Committees and Subcommittees that may have jurisdiction over various components of the Civilian Radioactive Waste Management Program are listed below.

\section{United States Senate}

\author{
Committee on Appropriations \\ S 128 Capital Building \\ Washington, DC 20510 \\ Chairman: Senator Robert C. Byrd \\ (West Virginia) \\ (202) 224-7235
}
Subcommittee on Energy and Water Development
136 Hart Senate Building
Washington, DC 20510
Chairman: Senator ). Bennett Johnston (Louisiana)
(202) 224-0335

\section{Committee on Armed Services}

SR-228 Russell Senate Office Building

Washington, DC 20510

Chairman: Senator Sam Nunn

(Georgia)

(202) 224-3871

\section{Committee on Commerce, Science and Transportation SD-508 Dirksen Senate Office Building Washington, DC 20510 \\ Chairman: Senator Ernest F. Hollings (South Carolina) \\ (202) 224-5115}

Subcommittee on Surface Transportation SH-428 Hart Senate Building

Washington, DC 20510

Chairman: Senator J. James Exon

(Nebraska)

(202) 224-5115

\section{Committee on Energy and Natural Resources \\ 136 Hart Senate Building \\ Washington, DC 20510 \\ Chairman: Senator J. Bennett Johnston (Louisiana) \\ (202) 224-4971}

Subcommittee on Energy Research

and Development

Dirkson Senate Office Building

Room 364

Washington, DC 20510-6150

Chairman: Senator Wendell H. Ford

(Kentucky)

(202) 224-4971

\section{Committee on Environment and Public Works \\ United States Senate \\ Washington, DC 20510 \\ Chairman: Senator Quentin N. Burdick (North Dakota) \\ (202) 224-4039}

\author{
Subcommittee on \\ Nuclear Regulation \\ United States Senate \\ Washington, DC 20510 \\ Chairman: Senator Bob Graham \\ (Florida) \\ (202) 224-3041
}

\section{Committee on Governmental Affairs \\ United States Senate \\ Washington, DC 20510 \\ Chairman: Senator John Glenn \\ (Ohio) \\ (202) 224-2627}

\section{United States House of Representatives}

\section{Committee on Appropriations \\ U.S. House of Representatives \\ Washington, DC 20515 \\ Chairman: Representative Jamie L. Whitten (Mississippi) \\ (202) 225-2771}

Subcommittee on Energy and Water Development

U.S. House of Representatives

Washington, DC 20515

Chairman: Representative Tom Bevill

(Alabama)

(202) 225-3421

\section{Committee on Armed Services \\ 2120 Rayburn House Office Building \\ Washington, DC 20515 \\ Chairman: Representative Les Aspin (Wisconsin) \\ (202) $225-4151$}

Subcommittee on Procurement and Military Nuclear Systems

2343 Rayburn House Office Building

Washington, DC 20515

Chairman: Representative Les Aspin (Wisconsin)

(202) 225-1240
Committee Panel on Environmental Restoration Chairman: Representative Richard Ray (Georgia)

Committee Panel on Department of Energy Defense Nuclear Facilities

Chairman: Representative John M. Spratt, Jr. (South Carolina) 


\section{Committee on Energy and Commerce}

2125 Rayburn House Office Building

U.S. House of Representatives

Washington, DC 20515

Chairman: Representative John D. Dingell (Michigan)

(202) 226-2500

Subcommittee on Energy and Power

U.S. House of Representatives

Room H2-331

Washington, DC 20515

Chairman: Representative Phillip R. Sharp (Indiana)

(202) 226-2500

\section{Committee on Government Operations}

2157 Rayburn House Office Building

U.S. House of Representatives

Washington, DC 20515

Chairman: John Conyers, Jr. (Michigan)

(202) 225-5051

\section{Committee on Interior and Insular Affairs}

1324 Longworth House Office Building

Washington, DC 20515

Chairman: Representative Morris K. Udall (Arizona)

(202) 225-2761

Subcommittee on Energy

and the Environment

U.S. House of Representatives

Washington, DC 20515

Chairman: Representative Morris K. Udall

(Arizona)

(202) 225-8331

\section{Committee on Science, Space and Technology}

2321 Rayburn House Office Building

Washington, DC 20510

Chairman: Representative George E. Bram (California)

(202) 225-6371

Subcommittee on Energy Research and Development

U.S. House of Representatives

Washington, DC 20515

Chairman: Representative Marilyn Lloyd

(Tennessee)

(202) 225-2884

\section{Congressional Support Agencies}

\section{General Accounting Office (GAO)}

441 G Street, NW

Washington, DC 20548

AssistantDirector-Resources, Community and Economic Division: Dwayne Weigel

(202) 586-8720

To order reports:

$\mathrm{GAO}$

P.O. Box 6015

Gaithersburg, MD 20877

\section{Office of Technology Assessment (OTA)}

600 Pennsylvania Avenue, SE

Washington, DC 20003

Publications Requests: (202) 224-8996 


\section{National and Regional Associations and Interest Groups}

\author{
American Nuclear Energy \\ Council (ANEC) \\ 410 First Street, SE \\ Washington, DC 20003 \\ (202) 484-2670 \\ Contact: Edward M. Davis, President \\ (202) 484-2670
}

\section{American Nuclear Society (ANS) \\ 555 N. Kensington Avenue \\ La Grange Park, IL \\ (708) 352-6611 \\ Contact: Joe Brandt, Executive Director}

\section{American Public Power}

Association (APPA)

$2301 \mathrm{M}$ Street, NW

Washington, DC 20037

(202) $775-8300$

Contact: Larry Hobart, Executive Director

American Society of Mechanical Engineers (ASME)

345 E. 47th Street

New York, NY 10017

(212 705-7722

Contact: Dr. David Belden, Executive Director

\section{American Trucking Association}

\section{(ATA)}

2200 Mill Road

Alexandria, VA 22314

(703) 838-1700

Contact: Thomas J. Donohue, CEO and President

\section{Association of American}

Railroads (AAR)

50 F Street, NW

Washington, DC 20001

(202) 639-2100

Contact: William H. Dempsey, President

Commercial Vehicle Safety Alliance (CVSA)

1620 I Street, NW, Suite 1000

Washington, DC 20006

(02) 775-5859

Contact: William R. Fiste, Executive Director

\section{Conference of Radiation Control} Program Directors, Inc. (CRCPD)

205 Capital Avenue

Frankfort, $\mathrm{KY}$

(502) 227-4545

Contact:Charles M. Hardin, Executive Secretary

\section{Conservation Foundation}

1250 24th Street, NW

Washington, DC 20037

(202) 293-4800

Contact: Gail Bingham, Vice-President

\section{Critical Mass Energy Project of Public Citizen \\ 215 Pennsylvania Avenue, SE \\ Washington, DC 20003 \\ (202) 546-4996 \\ Contact: Ken Bossong, Director}

Edison Electric Institute (EEI)

1111 19th Street, NW

Washington, DC 20036

(202) 778-6400

Contact: Steve Kraft

\section{Electric Power Research}

Institute (EPRI)

3412 Hillview Avenue

Palo Alto, CA 94303

(415) 855-2000

Contact: Richard Balzhiser, Executive Officer

Environmental Defense Fund (EDF)

257 Park Avenue, $\mathrm{S}$

New York, NY 10010

(212) $505-2100$

Contact: Frederic D. Knapp, Executive Director

Environmental Policy Institute (EPI)

218 D Street, SE

Washington, DC 20003

(202) 544-2600

Contact: Brent Blackwelder, Vice-President

Hazardous Materials Advisory

Council (HMAC)

1012 14th Street, NW, Suite 907

Washington, DC 20005

(202) $783-7460$

Contact: Paul Ranking, President
Institute of Nuclear Materials

Management (INMM)

60 Revere Drive, Suite 500

Northbrook, IL 60062

(708) 480-9080

Contact: John E. Messervey, Executive Director

\section{League of Women Voters}

Education Fund

$1730 \mathrm{M}$ Street, NW

Washington, DC 20036

(202) 429-1965

Contact: Grant $P$. Thompson, Executive Director

\section{The Council of State}

Governments (CSG)

641 E. Butterfield Road, Suite 401

Midwestern Lesgislative Conference Lombard, IL 60148

(708) $810-0210$

Contact: Tim Dantoin, Transportation Specialist

National Academy of Sciences (NAS)

Board on Radioactive Waste Management

2101 Constitution Avenue

Washington, DC

(202) 334-3066

Contact: Dr. Peter B. Myers

National Association of Attorneys General (NAAG)

444 N. Capital Street, NW

Washington, DC 20001

(202) 628-0435

Contact: Christine Milliken, Executive Director

National Association of Regulatory Utility Commissioners (NARUC)

P.O. Box 684

1102 ICC Building

Constitution Avenue and 12th Street, NW

Washington, DC 20044

(202) 898-2200

Contact: Paul Rogers, Administrative Director

\section{National Audubon Society}

950 Third Avenue

New York, NY 10022

(212) 832-3200

Contact: Peter A.A. Berle, President 


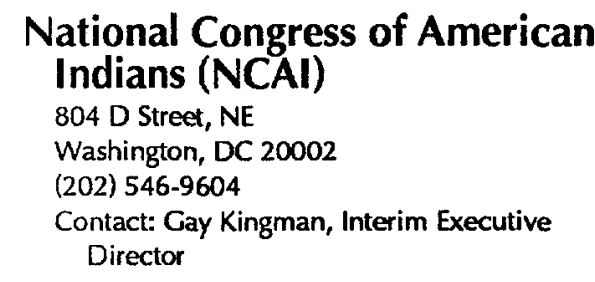

\section{National Governors Association} (NGA)

444 North Capitol Street, NW

Suite 250

Washington, DC 20001

(202) 624-5300

Contact: Raymond C. Sheppach, Executive Director
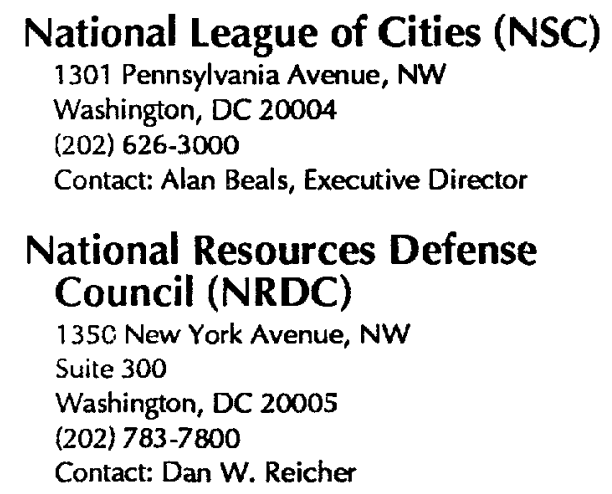

\section{Radioactive Waste Management} Associates

625 Broadway, Second Floor

New York, NY 10012

(212) 533-1583

Contact: Marvin Resnikoff

\section{Sierra Club}

730 Polk Street

San Francisco, CA 94109

(415) 776-2211

Contact: Michael Fischer, Executive Director

\section{Southern States Energy Board (SSEB)}

3091 Governors Lakes Drive, Suite 400

Norcross, GA 30071

(404) 242-7712

Contact: J. Michael Martinez, Assistant Director Policy Analysis

\section{Southwest Research and Information Center \\ P.O. Box 4524 \\ Albuquerque, NM 87106 \\ (505) 262-1862 \\ Contact: Don Hancock, Administrator}

\section{Union of Concerned Scientists}

26 Church Street

Cambridge, MA 02238

(617) 547-5552

Contact: Howard C. Ris, Jr., Executive Director

\author{
U.S. Council for Energy \\ Awareness (USCEA) \\ 1776 I Street, NW \\ Washington, DC \\ (202) 293-0770 \\ Contact: Steven Sklar
}

\author{
Western Governors Association \\ (WGA) \\ 60017 th Street \\ 1205 S. Tower \\ Denver, $\mathrm{CO}$ \\ Contact: Ron Ross
}
Western Interstate Energy Board (WIEB)
6500 Stapleton Avenue
3333 Quebec Street
Denver, CO 80202
(303) $377-9459$
Contact: Lori Friel




\section{Locating Program Documents}

A variety of program documents are available at DOE Public Reading Rooms and Information Offices. OCRWM also maintains a list of public libraries that receive a variety of OCRWM materials. NRC materials are available at the listed NRC Local Public Document rooms. For further information about the Local Public Document Room Program, call (800) 638-8081.

\section{DOE Public Reading Rooms}

U.S. Department of Energy

Public Reading Room

Room 1E-190

1000 Independence Ave., SW

Washington, DC 20585

(202) $586-6020$

Albuquerque Operations Office

National Atomic Museum

Post Office Box 5400

Kirtland Air Force Base, E

Albuquerque, NM 87115

(505) 844-8443

Bartlesville Project Office/National institute

for Petroleum and Energy Research

(NIPER) Library

U.S. Department of Energy

220 N. Virginia Avenue

P.O. Box 2128

Bartlesville, OK 74003

(918) $337-4371$

Boston Support Office

U.S. Department of Energy

10 Causeway Street

Room 1197

Boston, MA 02222-1035

(617) 565-7700

Chicago Operations Office

Building 201

9800 South Cass Ave.

Argonne, IL 60439

(708) 972-2010

Idaho Operations Office

Public Reading Room, INEL Technical Library

1776 Science Center Drive

Idaho Falls, ID 83402-2300

(208) 526-1144
Nevada Operations Office

Public Reading Room

U.S. Department of Energy

P.O. Box 98518

Las Vegas, NV 89193-8518

(702) 295-1274

Oak Ridge Operations Office

U.S. Department of Energy

P.O. Box 2001

Oak Ridge, TN $37831-8510$

(615) 576-1221

Pittsburgh Energy Technology Center U.S. Department of Energy

Cochran Mill Road, Building 95

P.O. Box 10940

Pittsburgh, PA 15236-0940

(412) 892-4751

Richland Operations Office

Public Reading Room

Al-65

P.O. Box 1970

Richland, WA 99352

(509) 376-8583

Rocky Flats Area Office c/o Front Range Community College 3645 West 112 Avenue

Westminister, CO 80030

(303) 469-4435

San Francisco Operations Office

Wells Fargo Bank Bldg.

1333 Broadway

Oakland, CA 94612

(415) $273-4428$
Savannah River Operations Office DOE Public Documents Reading Room

Gregg-Graniteville Library

Second Floor

University of South Carolina-Aiken

171 University Parkway

Aiken, SC 29801

(803) 648-6851 (Extension 3320)

Southeastern Power Administration

U.S. Department of Energy

Legal Library

Samuel Elbert Building, Public Square

Elberton, GA 30635

(404) 283-9911

\section{DOE Information Offices}

\section{Nevada}

Yucca Mountain Information Office

P.O. Box 69

Beatty, NV 89003

Staff: Shirley Tarr

Phone: (702) 553-2130

Hours: 10 a.m. -3 p.m., Mon.-Fri. 12 p.m.-5 p.m., Sat., Sun.

Yucca Mountain Information Office 4101B Meadows Lane Las Vegas, NV 89107

Staff: Effie Harle

Phone: (702) 295-1312

Hours: 12 a.m. -6 p.m., Mon.

10 a.m.-6 p.m., Tues.-Sat. 1 p.m.-5 p.m., Sun.

\section{NRC Local Public Document Rooms}

University of Nevada, Las Vegas Special Collections Department James R. Dickinson Library 4505 Maryland Parkway

Las Vegas, NV 89154

Documents Specialist: Dennis McBride

Phone: (702) 739-3252
University of Nevada, Reno

Library - Government Publications Department Reno, NV 89557-0044

Covernment Publications Librarian: Janita Jobe

Phone: (702) 784-6579 


\section{Nevada Public Libraries}

The public libraries listed below are on OCRWM's mailing lists.

Lists of other libraries are available upon request. Public libraries may be added to the list by contacting:

\section{U.S. Department of Energy}

Office of Civilian Radioactive Waste Management

Education and Information Division

1000 Independence Avenue, SW

Washington, DC 20585

(202) 586-5722

Amargosa Valley Community Library

HCR 69-2

P.O. Box 401-T

Amargosa Valley, NV 89020

(702) $372-5340$

Beatty Community Library

P.O. Box 129

Beatty, NV 89003

(702) $553-2257$

Clark County Library District

Reference Department

1401 E. Flamingo Rd.

Las Vegas, NV 89119

(702) 732-0730

Nevada State Library

Capital Complex and Archives

401 North Carson Street

Carson City, NV 89710

(702) 687-5160

Tonopah Public Library

P.O. Box 449

Tonopah, NV 89049

(702) 482-3374
U.S. DOE/NV Technical Library

P.O. Box 98518

Las Vegas, NV 89193-8518

(702) 295-1274

University of Nevada, Las Vegas

James R. Dickinson Library

4505 Maryland Parkway

Las Vegas, NV 89154

(702) 739-3521

University of Nevada, Reno

Getchell Library

Reno, NV 89557

(702) 784-6508

Washoe County Library

P.O. Box 2151

Reno, NV 89505

(702) 785-4518 


\section{Index of Systems}

\section{DOE Technical Data Bases}

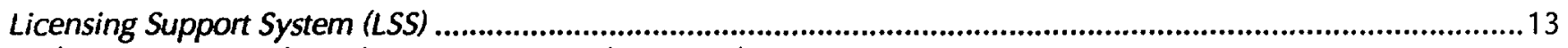

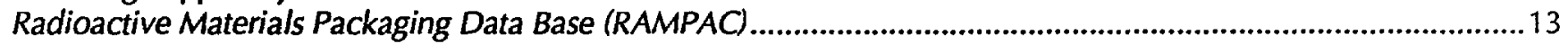

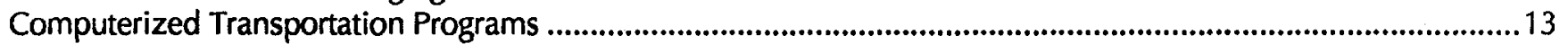

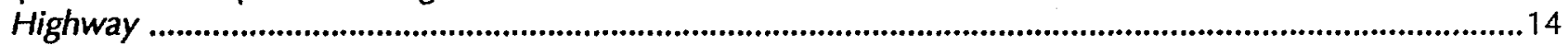

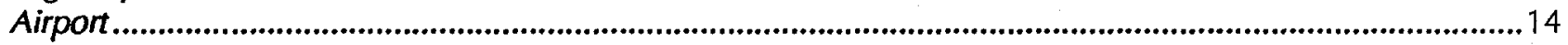

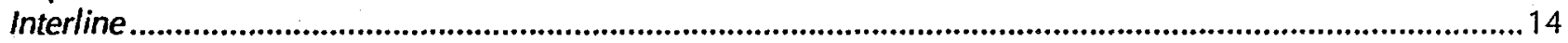

Transportation Legislative Data Base (TLDB) ….....................................................................................15

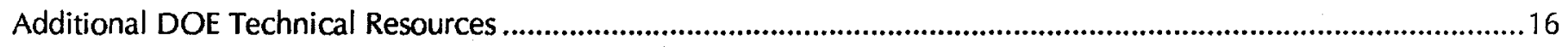

Technical Publications and Data Bases: Office of Scientific and Technical Information ......................................16

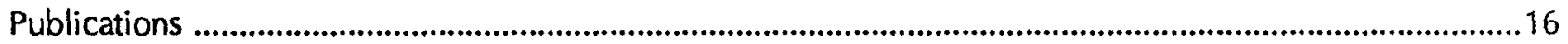

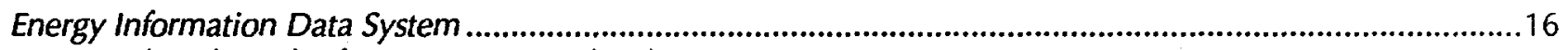

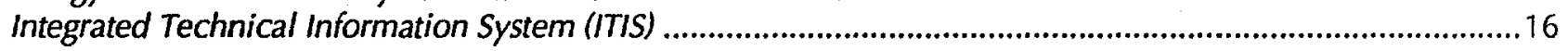

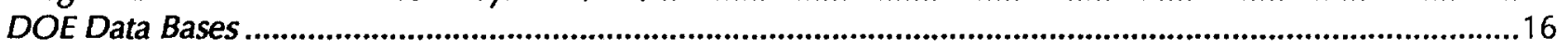

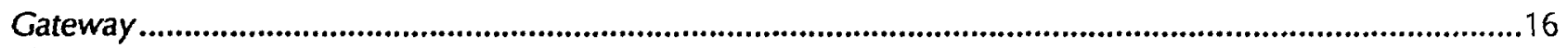

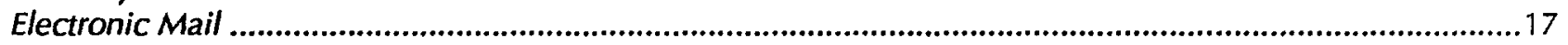

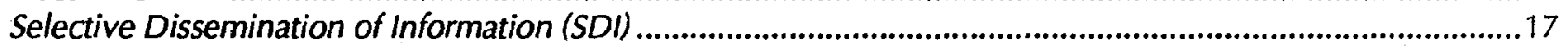

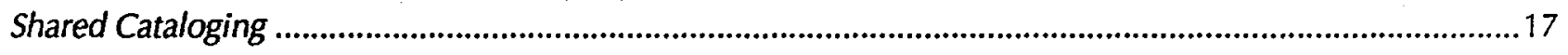

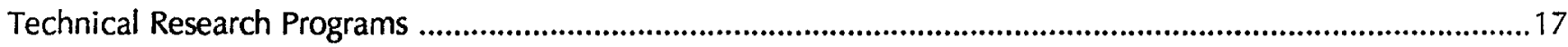

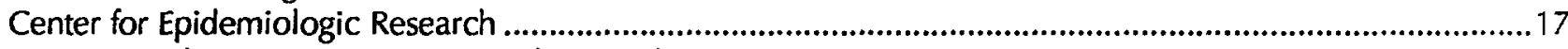

Experimental Reservoir Engineering Flow Facility ................................................................................17

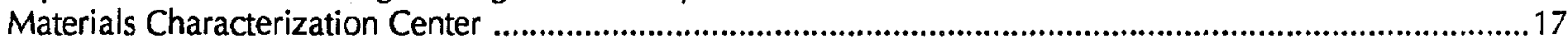

Nuclear Operations Analysis Center ................................................................................................................18

Radiation Emergency Assistance Center (REAC/TS) ..................................................................................... 18

Technical Software Programs: National Energy Software Center...................................................................19

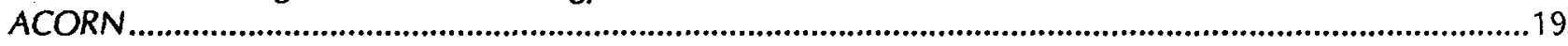

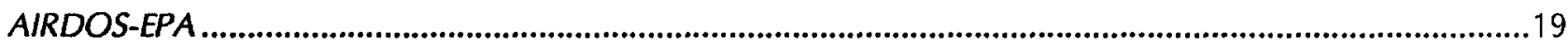

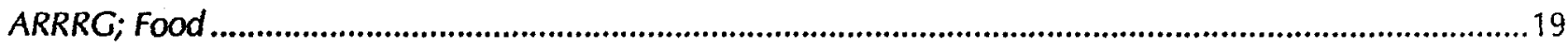

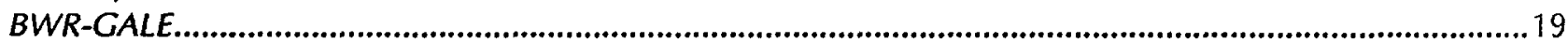

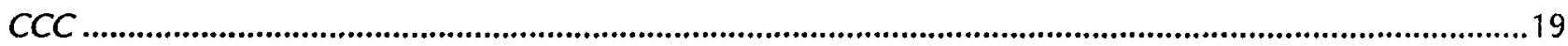

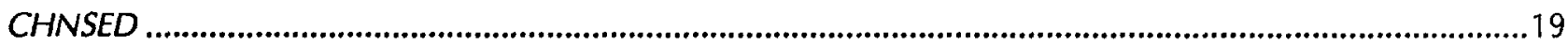

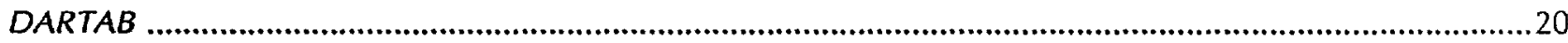

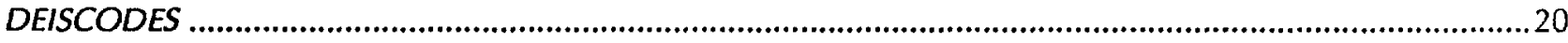

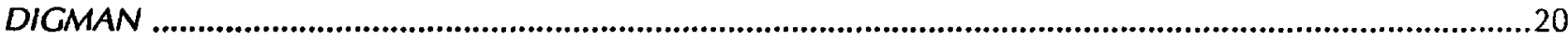

DOT-BPMD

EQ3,EQ6

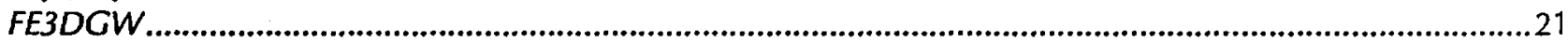

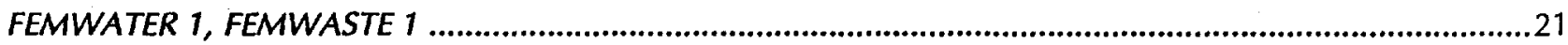

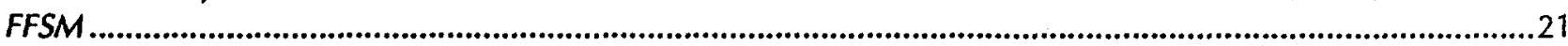

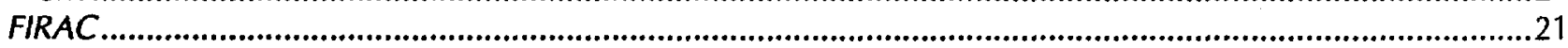

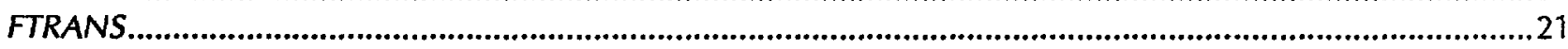

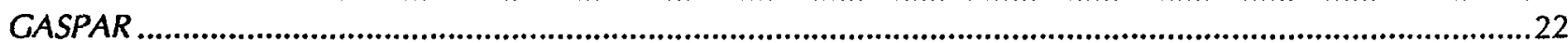


GEOTHER

GSM

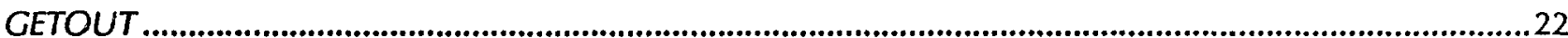

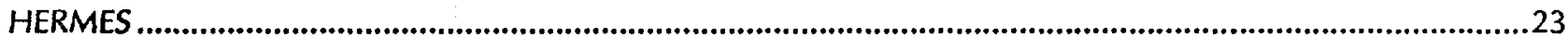

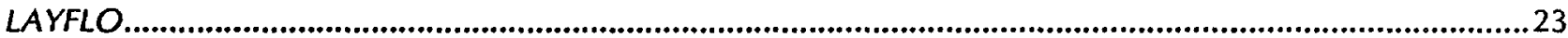

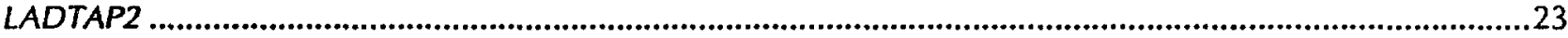

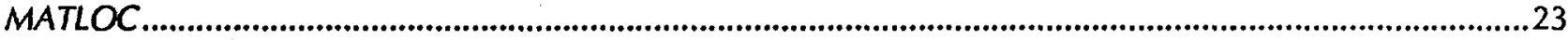

MESOI2.0

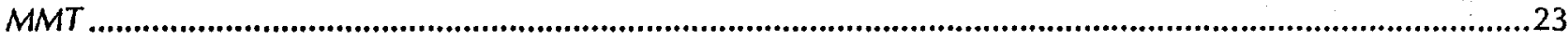

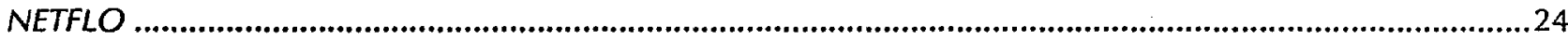

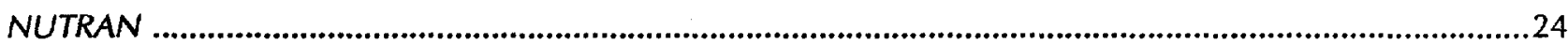

ODMOD

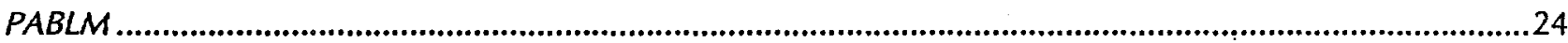

PFPL

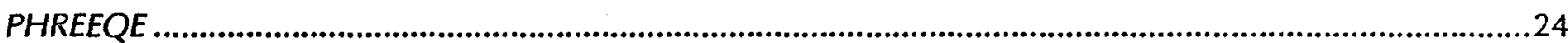

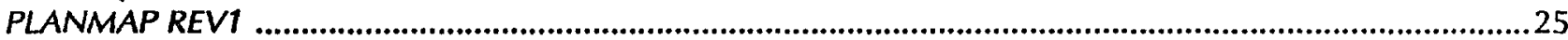

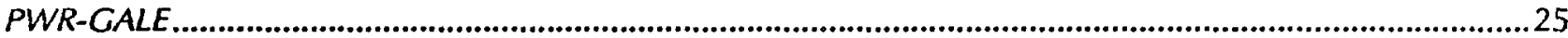

RABFIN, PARTS

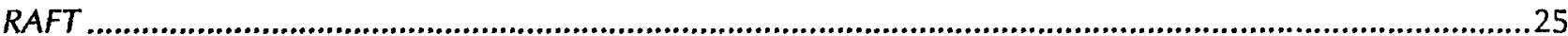

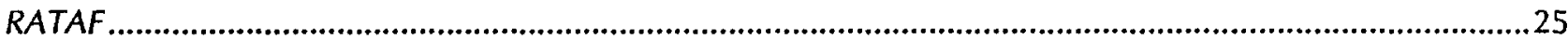

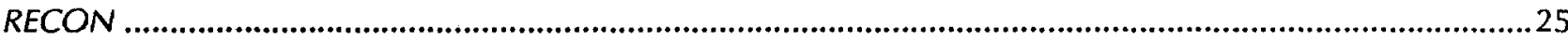

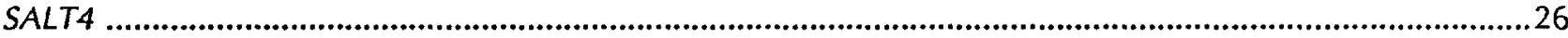

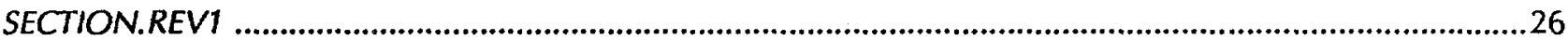

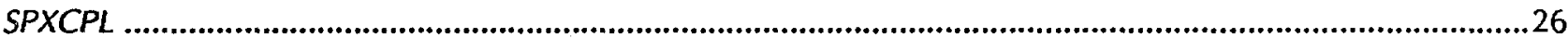

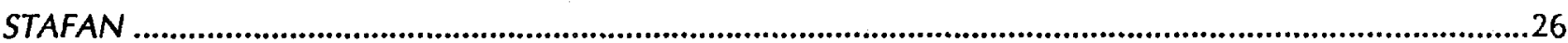

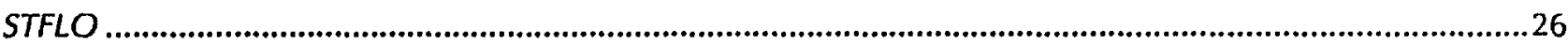

SWENT

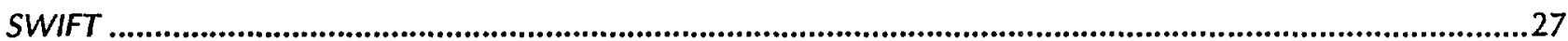

THORIN, INTERP

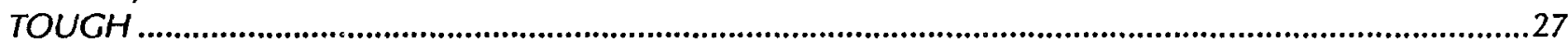

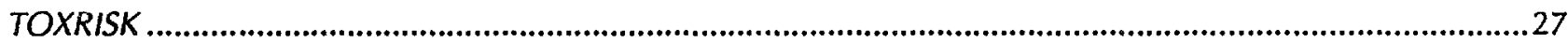

TRIPM

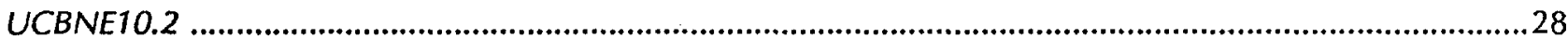

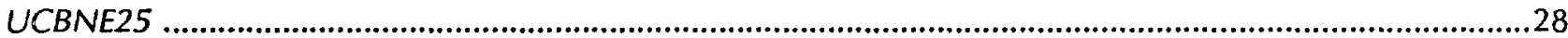

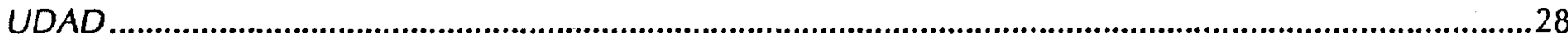

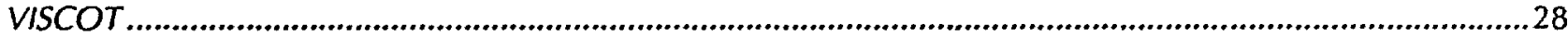

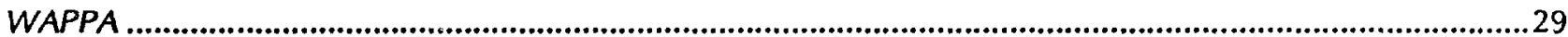

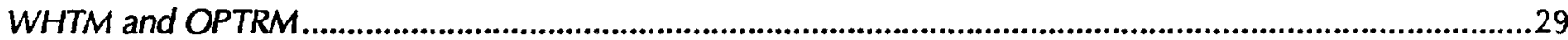

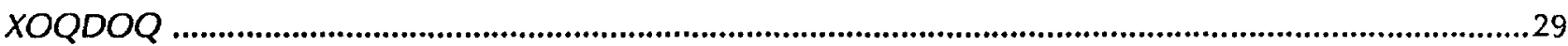




\section{List of Selected Publications}

OCRWM publishes a number of printed products which cover a variety of areas related to the integrated waste management system. These publications are available to the public upon request and may be ordered by sending the document number and title to the following address:

\section{U.S. Department of Energy}

Office of Civilian Radioactive Waste Management

Education and Information Division

1000 Independence Avenue, SW

Washington, DC 20585

The Nuclear Waste Policy Act of 1982 (OCRWM/PI-003)

This Act established the national policy for the disposal of high-level nuclear waste. January 1983. $64 \mathrm{pp.}$

Federal Register, Volume 49, Number 236, 12/06/84, 10CFR, Part 960, General Guidelines for the Recommendation of Sites for the Nuclear Waste Repositories (OCRWM/PI-004)

This part of the Federal Register pertains to the NWPA general guidelines for the Recommendation of Sites for the Nuclear Waste Repositories. December 1984. 56 pp.

Federal Register, Volume 52, Number 39, 2/27/87, Definition of "High Level Radioactive Waste" (OCRWM/PI-008)

The Nuclear Regulatory Commission identifies legal and technical considerations pertinent to the definition of highlevel waste and solicits public comment on alternative approaches to a revised definition. February $1987.10 \mathrm{pp}$.

Federal Register, Volume 51, Number 231, 12/2/86, Calculating Nuclear Waste Fund Disposal Fees for DOE Defense Program Waste (OCRWM/PI-009)

DOE gives public notice of its tentative approach to interpreting the requirement under the NWPA for disposal of defense high-level waste in a civilian repository. December 1986. $6 \mathrm{pp}$.

Federal Register, Volume 51, Number 146, 7/30/86, Disposal of High-Level Radioactive Wastes in Geologic Repositories (OCRWM/PI-020)

The NRC amends its regulations applicable to the disposal of high-level radioactive wastes in geologic repositories to deal with procedural aspects of site characterization and the participation of States and Indian Tribes. July 1986. $8 \mathrm{pp}$.

The Nuclear Waste Policy Amendments Act of 1987 (OCRWM/PI-025)

This Act amended the Nuclear Waste Policy Act of 1982 for the disposal of high-level nuclear waste. December 1987. $30 \mathrm{pp}$.

What Happens During Site Characterization? (OCRWM/PI-027)

This factsheet outlines the extensive tests at Yucca Mountain, Nevada, in the next 5 to 7 years to determine the site suitability for a high-level radioactive waste repository. April 1988. 2 pp. 
Supplying the Yucca Mountain Project (OCRWM/PI-028)

This factsheet outlines the ways in which materials and equipment required during site characterization may be obtained through private contractors located in southern Nevada. April 1988. 2 pp.

Why Yucca Mountain? (OCRWM/PI-029)

This factsheet describes the geologic and hydrologic conditions of the Yucca Mountain site that DOE believes are conducive to isolating high-level radioactive waste. March 1988. $2 \mathrm{pp}$.

What is Tuff? (OCRWM/PI-030)

This factsheet discusses the rock type being studied for housing a repository for high-level radioactive waste. March 1988. 2 pp.

Nuclear Waste Fund Fee Adequacy: An Assessment (DOE/RW-0291P)

This report evaluates the adequacy of the fees assessed to cover costs for the disposal of high-level radioactive waste. November 1990. $16 \mathrm{pp}$.

Quality Assurance Management Policies and Requirements (DOE/RW-0032)

This document sets forth a framework for achieving and assuring quality in technical processes and products.

October 1985. 24 pp.

Internal Guidelines for Interactions with Communities and Local Governments (DOE/RW-0039)

These guidelines provide policy direction to OCRWM's program implementing offices, while preserving their ability to tailor local interactions to fit a given situation. November $1985.19 \mathrm{pp}$.

Program Management System Manual (DOE/RW-0043)

This document describes the hierarchy of plans required to develop and maintain the cost, schedule and technical baselines at the various organizational levels of OCRWM. January 1986. $62 \mathrm{pp}$.

Transportation Business Plan (DOE/RW-0046)

This document sets the context for business strategy decisions by providing background information and describing

legislation and policies governing transportion under the NWPA. January 1986. $54 \mathrm{pp}$.

Analysis of the Total System Life Cycle Cost for the Civilian Radioactive Waste Management Program (DOE/RW-0047)

This report provides cost estimates for the fifth evaluation of the adequacy of the fee levied on electricity generated in commercial nuclear power plants in covering the cost of the civilian waste management program. June 1987. Vol. 1-100 pp; Vol. 2-130 pp.

Waste Management Systems Requirements and Descriptions (DOE/RW-0063)

This document covers the functional requirements to achieve the mission of the waste management system and includes performance criteria for those functions. January 1986. $54 \mathrm{pp}$.

A Multiattribute Utility Analysis of Sites Nominated for Characterization for the First Radioactive Waste Repository A Decision-Aiding Methodology (DOE/RW-0074)

This is a formal application of one of the three quantitative methods that were used to aggregate rankings assigned to each of the five candidate repository sites for the various technical guidelines. May 1986. $458 \mathrm{pp}$. 
Environmental Assessment Overview, Yucca Mountain Site, Nevada Research and Development Area, Nevada (DOE/RW-0079)

This is an overview of the final environmental assessment that was conducted to assess environmental impacts from the siting of a high-level radioactive waste repository at Yucca Mountain, Nevada. May 1986. 36 pp.

Public Information Guidelines (DOE/RW-0089)

These guidelines provide principles for the implementation of the NWPA mandate and the Mission Plan requirements for the provision of public information. June $1986.166 \mathrm{pp}$.

Transportation Institutional Plan (DOE/RW-0094)

This plan describes policy guidance for developing an integrated system for transporting spent nuclear fuel, the major participants, mechanisms for interaction, and a framework for issues management and resolution. August 1986. $212 \mathrm{pp}$.

\section{Quality Assurance Directive (DOE/RW-0103)}

This directive provides policy guidance, organizational procedures and minimum requirements for ensuring the quality of all programs under direction of the Office of Storage and Transportation Systems. October 1986. $10 \mathrm{pp}$.

\section{OCRWM Safety Plan (DOE/RW-0119)}

This Plan sets forth management policies and general requirements for the safety of the public and of personnel associated with OCRWM. December 1986. 20 pp.

\section{Addressing Concerns about Water Through Repository Siting and Design (DOE/RW-0123)}

This backgrounder discusses DOE's siting guidelines to ensure the isolation of high-level nuclear waste from the accessible environment via surface water, groundwater and precipitation. January 1987. 2 pp.

Waste Acceptance Preliminary Specifications for the Defense Waste Processing Facility High-Level Waste Form (DOE/RW-0125)

This report specifies properties and requirements for the high-level waste forms to be produced by the Defense Waste Processing Facility at the Savannah River Plant. December 1986. 24 pp.

Waste Acceptance Preliminary Specifications for the West Valley Demonstration Project High-Level Waste Form (DOE/RW-0136)

This report specifies the properties and requirements for the high-level waste forms to be produced by the West Valley Demonstration Project at West Valley, New York. April 1987. 27 pp.

Cooperative Demonstration Projects for Spent Nuclear Fuel (DOE/RW-0138)

This backgrounder describes several technology demonstration projects that DOE is implementing in cooperation with the nuclear power industry. April 1987. $6 \mathrm{pp}$.

Transportation Institutional Plan — Executive Summary (DOE/RW-0143)

This summary provides an overview of the Transportation Institutional Plan which defines a comprehensive process for effective interaction among those affected by a transportation program for spent fuel and high-level radioactive waste. April 1987. $6 \mathrm{pp}$. 
Site Characterization Plan Overview - Consultation Draft. Yucca Mountain Site, Nevada Research and Development Area, Nevada (DOE/RW-0161)

This overview contains brief summaries of important topics covered in the consultation draft of the site characterization plan provided to the State of Nevada and the Nuclear Regulatory Commission. January 1988. $119 \mathrm{pp}$.

Health and Safety Protection in the Management of the Nation's High-Level Radioactive Waste (DOE/RW-0169)

This backgrounder describes OCRWM's approach to protecting the health and safety of the public against the potential risks of radioactive waste disposal. May 1988. $3 \mathrm{pp}$.

Environmental Monitoring and Mitigation Plan for Site Characterization (Revision 1) (DOE/RW-0176)

This plan has been developed by OCRWM for use during site characterization activities in response to the NWPA stipulation that these activities be conducted in a manner that minimizes any significant adverse environmental impacts. January 1988. $146 \mathrm{pp}$.

Environmental Regulatory Compliance Plan for Site Characterization of the Yucca Mountain Site (DOE/RW-0177)

This report describes the plans by which site characterization at the Yucca Mountain site will comply with applicable environmental statutes and regulations. December 1987. $202 \mathrm{pp}$.

Socioeconomic Monitoring and Mitigation Plan for Site Characterization (Rev. 1) (DOE/RW-0179)

This is a summary description of the potential for socioeconomic impacts from site characterization activities, identifying issues pertaining to monitoring and mitigating the impacts. January 1988. $152 \mathrm{pp}$.

Characteristics of Spent Fuel, High-Level Waste, and Other Radioactive Wastes which may Require Long-Term Isolation (DOE/RW-0184)

This technical report establishes the OCRWM reference characteristics of the waste materials that may be accepted by DOE for emplacement in a repository and is accompanied by 5 PC-compatible databases. December 1987. $1,458 \mathrm{pp}$. In revision, expected publication date September 1991.

Draft 1988 Mission Plan Amendment (DOE/RW-0187)

This report to Congress presents DOE's plans for implementing the provisions of the Amendments Act for the waste management program. June 1988. $98 \mathrm{pp}$.

Annual Report to Congress, August 1988 (DOE/RW-0189)

This fifth annual report to Congress, as required by the NWPA, covers the activities and expenditures of OCRWM during fiscal year 1987. August 1988. $61 \mathrm{pp}$.

OCRWM Transportation Program Reference (DOE/RW-0193)

This booklet of reference information for the OCRWM transportation program includes a glossary, an acronym list and a selected bibliography. July 1988. $28 \mathrm{pp}$.

Site Characterization Plan Overview - Yucca Mountain Site, Nevada Research and Development Area, Nevada (DOE/RW-0198)

This overview presents summaries of selected topics covered in the Site Characterization Plan for the Yucca Mountain site and gives brief descriptions of the site. December 1988. 164 pp. 
Section 175 Report: Secretary of Energy's Report to the Congress pursuant to Section 175 of the Nuclear Waste Policy Act, as Amended. (DOE/RW-0205)

This report to Congress analyzes DOE authorities and sources of funds to be administered in close consultation with the State and affected units of local government to address impacts. December 1988. $126 \mathrm{pp}$.

Site Characterization Plan - Public Handbook - Yucca Mountain, Nevada. (DOE/RW-0206)

This is a summary of the 9-volume Plan describing the activities to be conducted to characterize the geologic, hydrologic and other conditions relevant to site suitability for a repository. January $1989.28 \mathrm{pp}$.

\section{Annual Report to Congress (DOE/RW-0216)}

This sixth Annual Report to Congress by OCRWM describes activities and expenditures by the office during fiscal year 1988. January 1990. [60 pp.]

Progress Report on the Scientific Investigation Program for the Nevada Yucca Mountain Site - Number 1 (DOE/RW0217P)

This report summarizes the status of scientific investigations at the Yucca Mountain Site in Nevada during the period September 15, 1988, through September 30, 1989. February 1990. 75 pp.

Implementation Plan for Deployment of Federal Interim Storage Facilities for Commercial Spent Nuclear Fuel (DOE/RW-0218)

This sixth annual report describes plans for providing Federal Interim Storage (FIS) capacity. December 1988. 15 pp.

Final Version Dry Cask Storage Study (DOE/RW-0220)

This study evaluates the use of dry-cask storage technologies for temporary storage of spent nuclear fuel at civilian nuclear power reactors until a permanent geologic repository has been constructed and licensed. December 1988. $354 \mathrm{pp}$.

The Yucca Mountain Story (DOE/RW-0224)

This booklet provides a general overview of the waste management program. September $1989.20 \mathrm{pp}$. In revision as "DOE's Yucca Mountain Studies." Expected publication date March 1991.

MRS System Study Summary Report (DOE/RW-0235)

This report reviews the potential role of a monitored retrievable storage facility in the national waste management system. June $1989.134 \mathrm{pp}$.

Analysis of the Total System Life Cycle Cost for the Civilian Radioactive Waste Management Program (DOE/RW-0236)

This cost analysis is performed on a regular basis to ensure that monies collected in the Nuclear Waste Fund are sufficient to pay for the cost of the waste management program. June 1989. $184 \mathrm{pp}$.

The DOE Position on the MRS Facility (DOE/RW-0239)

This report presents the DOE perspective on the importance of a monitored retrievable storage facility as an integral component of the waste management system. June 1989. $26 \mathrm{pp}$.

Studies of Alternative Methods of Radioactive Waste Disposal (DOE/RW-0240)

This backgrounder provides an overview of various alternative nuclear waste disposal methods. July 1989. 5 pp. 
Federal Agencies Involved in the Implementation of the Nuclear Waste Policy Act of 1982 (DOE/RW-0241)

This report describes several Federal agencies that help to implement provisions of the NWPA, as amended. July 1989. $4 \mathrm{pp}$.

Geographic Distribution of High-Level Radioactive Waste (DOE/RW-0242)

This backgrounder graphically depicts the actual and anticipated geographic distribution of spent nuclear fuel and high-level waste. June 1989. 2 pp.

OCRWM Publications Catalog on High-Level Radioactive Waste Management (DOE/RW-0243)

This catalog provides citations of selected technical and public information on the subject of high-level radioactive waste management. Also available online through OCRWM's INFOLINK. July 1989. 304 pp.

\section{Draft Reclamation Program Plan for Site Characterization (DOE/RW-0244)}

This report reviews the draft plan for environmental reclamation of Yucca Mountain following site characterization activities. August 1989. $32 \mathrm{pp}$.

Report to Congress on Reassessment of the Civilian Radioactive Waste Management Program (DOE/RW-0247)

This report presents the results of a DOE review of the civilian radioactive waste management program and the subsequent management plans that have been initiated to achieve the successful implementation of key program elements. November 1989. 22 pp.

Executive Summary - Report to Congress on Reassessment of the Civilian Radioactive Waste Management Program (DOE/RW-0248)

This executive summary states, in brief, the principal points of a report to Congress by DOE on management initiatives. (See DOE/RW-0247). November 1989. 2 pp.

Changes in the Geologic Repository Schedule (DOE/RW-0249)

This backgrounder presents the changes in the repository schedule as described and discussed in November 1989 and the management plans proposed to achieve key program goals. November 1989. $2 \mathrm{pp}$.

The Role of the Monitored Retrievable Storage Facility in an Integrated Waste Management System (DOE/RW-0250)

This backgrounder discusses the importance of a monitored retrievable storage facility in the national high-level radioactive waste management system. December 1989. 3 pp.

Integrating Contractor Efforts in the Civilian Radioactive Waste Management Program (DOE/RW-0251)

This backgrounder discusses ways in which contractor support can be better integrated into the management structure and schedule of the waste management program. December 1989. $2 \mathrm{pp}$.

Restructuring the Office of Civilian Radioactive Waste Management (DOE/RW-0252)

This backgrounder reviews several initiatives taken to streamline and strengthen OCRWM. December 1989. $2 \mathrm{pp}$.

Cask Systems Development: Titan Truck Cask (DOE/RW-0255)

This backgrounder describes the Westinghouse Titan spent fuel shipping cask for legal-weight truck shipments. February 1990. 2 pp. 
Cask Systems Development: NuPac 140-B Rail/Barge Cask (DOE/RW-0256)

This backgrounder describes the NuPac 140-B spent fuel shipping cask for rail and barge shipments. February 1990. 2 pp.

Cask Systems Development: BR-100 Rail/Barge Cask (DOE/RW-0257)

This backgrounder describes the Babcock \& Wilcox BR-100 spent fuel shipping cask for rail and barge shipments. February 1990. 2 pp.

Cask Systems Development: GA-4 \& GA-9 Truck Cask (DOE/RW-0258)

This backgrounder describes the General Atomics GA-4 and GA-9 spent fuel shipping casks for legal-weight truck shipments. February 1990. 2 pp.

Cask Systems Development: NAC-CTC Rail/Barge Cask (DOE/RW-0259)

This backgrounder describes the Nuclear Assurance Corporation NAC-CTC spent fuel shipping cask for rail and barge shipments. February 1990. 2 pp.

1989 OCRWM Bulletin Compilation and Index (DOE/RW-0262)

This document is a compilation of OCRWM Bulletins (program newsletters) from the 1989 calendar year. An index is provided. February 1990. $75 \mathrm{pp}$.

Managing the Nation's Nuclear Waste (full-color brochure) (DOE/RW-0263P)

This brochure, produced in cooperation with the Nuclear Energy Agency of the Organization for Economic Cooperation and Development, outlines the national program for disposing of spent fuel and high-level radioactive waste. March 1990. $6 \mathrm{pp}$.

International Cooperation in Nuclear Waste Management (DOE/RW-0263P+)

This factsheet accompanies the brochure "Managing the Nation's Nuclear Waste" (DOE/RW-0263P) and describes cooperative efforts worldwide to share the cost of nuclear waste disposal testing programs and exchange information and experience. March 1990. 2 pp.

Major Federal Regulations Which Affect the Civilian Radioactive Waste Management Program (DOE/RW-0273P)

This backgrounder presents a summary of the Federal Government Codes with which DOE must comply in its licensing, packaging, transport, and storage of nuclear waste. May 1990. 2 pp.

The Status of the Nuclear Waste Fund (DOE/RW-0274P)

This backgrounder presents a summary of the status of the Nuclear Waste Fund, which is used to finance activities mandated under the NWPA of 1982. May 1990.1 p.

Performance Assessment Under the Geologic Repository Program (DOE/RW-0275P)

This backgrounder describes the use of performance assessments to guide repository testing, design, and site characterization activities and to identify and evaluate possible impacts of a repository on health, safety, and the environment. May 1990. $6 \mathrm{pp}$. 
Emergency Preparedness for Radioactive Materials Transport (DOE/RW-0276P)

This backgrounder presents a summary of the Federal programs that are designed to provide effective response to transportation emergencies during the shipment of radioactive materials and describes training programs for public safety officials along shipping routes. May $1990.5 \mathrm{pp}$.

Transportation Casks for Spent Nuclear Fuel and High-Level Radioactive Waste (DOE/RW-0277P)

This backgrounder describes the role and types of transportation casks that are being developed for the nuclear waste management system. May 1990. 3 pp.

Transportation Routing Issues Related to the Shipment of High-Level Nuclear Waste (DOE/RW-0278P)

This backgrounder provides a review of major highway and rail routing issues identified by OCRWM and interested parties. May $1990.3 \mathrm{pp}$.

Addressing Concerns About Water Through Repository Siting and Design (DOE/RW-0279P)

This backgrounder describes DOE siting guidelines for selection of a repository that will safely isolate high-level nuclear waste from all sources of water including those from surface, ground, and precipitation sources. May 1990. $2 \mathrm{pp}$.

Shipments of Spent Nuclear Fuel in Support of Nuclear Waste Policy Act Research and Development Programs (DOE/RW-0280P)

This backgrounder reviews the shipping requirements and procedures that guide shipments of spent fuel assemblies in support of OCRWM research and development programs. May 1990. 2 pp.

Quality Assurance for Nuclear Waste Repositories (DOE/RW-0281P)

This backgrounder discusses the types of activities subject to quality assurance (QA) program requirements and the specific requirements and activities of the QA program. May 1990. $3 \mathrm{pp}$.

Characteristics and Inventories of Nuclear Waste (DOE/RW-0283P)

This backgrounder describes the two forms of nuclear waste, spent fuel and defense waste, that will be disposed of in civilian repositories. May $1990.3 \mathrm{pp}$.

Radiation and High-Level Radioactive Waste (DOE/RW-0284P)

This backgrounder provides information about the sources, effects and relative risks of ionizing radiation. May 1990. 4 pp.

The Multiple Barrier System of Geologic Disposal of Spent Nuclear Fuel and High-Level Radioactive Waste (DOE/RW-0285P)

This backgrounder describes the system of both engineered and natural barriers to contain the nuclear waste in a geologic repository. May 1990. $4 \mathrm{pp}$. 
Nuclear Waste Fund Fee Adequacy: An Assessment (DOE/RW-0291P)

This report evaluates the adequacy of the fees assessed to cover costs for the disposal of high-level radioactive waste. November 1990. $16 \mathrm{pp}$.

Progress Report on the Scientific Investigation Program for the Nevada Yucca Mountain Site - Number 2 (DOE/RW-0292P)

This report summarizes the status of scientific investigations at the Yucca Mountain Site in Nevada during the period October 1, 1989, through March 31, 1990. October 1990. 74 pp.

\section{Annual Capacity Report (DOE/RW-0294P)}

This report is issued to assist planning relative to the projected annual receiving capacity, set forth in NWPA, of the waste management system for 10 years following projected commencement of facility operation. December 1990. $90 \mathrm{pp}$. 